\title{
к-Opioid Receptor Agonists Modulate Excitatory Transmission in Substantia Gelatinosa Neurons of the Rat Spinal Cord
}

\author{
M. Randić, G. Cheng, ${ }^{a}$ and L. Kojic ${ }^{b}$ \\ Department of Veterinary Physiology and Pharmacology, lowa State University, Ames, lowa 50011
}

This study examined the effects of selective activation of $\kappa_{1}$-opioid receptors on excitatory transmission in substantia gelatinosa (SG) using intracellular recordings from SG neurons in transverse slices of the young rat lumbar spinal cord. Monosynaptic and polysynaptic excitatory postsynaptic potentials (EPSPs) were evoked by orthodromic electrical stimulation of $A \delta$ or $C$ primary afferent fibers in the dorsal root after blocking inhibitory inputs with bicuculline and strychnine, NMDA receptors with D-2-amino-5-phosphonovaleric acid and $\mu$ - and $\delta$-opioid receptors with CTAP and $\mathrm{ICl} 174,864$, respectively. Bath application of dynorphin $A_{1-17}$ or $U-69,593$ caused dual modulation of the peak amplitude of presumed monosynaptic AMPA receptor-mediated EPSPs, decreasing synaptic potentials at nanomolar concentrations in a majority of SG cells examined (dynorphin, 63\%; U-69,593, 91\%), and increasing EPSPs at micromolar concentrations. Only the inhibitory action of dynorphin $A_{1-17}$ was consistently and completely blocked by norbinaltorphimine (nor-BNI). Since U-69,593 and nor-BNI are selective for the $\kappa_{1}$-opioid receptors, the depression of EPSPs is likely to be mediated by the $\kappa_{1}$-opioid receptors. Under conditions of blockade of synaptic transmission with TTX and $\mu$ - and $\delta$-opioid receptors, dynorphin $A_{1-17}$ and U-69,593 hyperpolarize most of SG neurons and decrease their membrane input resistance, the finding suggesting that direct interaction of $\kappa$-agonists with a postsynaptic receptor is likely explanation for the inhibition of EPSPs. However, in some SG cells, the inhibition of EPSPs appears to be of presynaptic origin since dynorphin $A_{1-17}$ and $\mathrm{U}-69,593$ did depress the EPSPs in the absence of changes in passive membrane properties. Rp-CAMPS, a membrane permeant potent competitive inhibitor of cAMP-activated protein kinase, prevented the depressant effect of dynorphin $A_{1-17}$. This finding suggested a possibility that dynorphin $A_{1-17}$, acting through a decrease in intracellular cyclic AMP levels, can reduce the synaptic responses of SG neurons. These results provide the first electrophysiological demonstration that the activation of $\kappa_{1}$-opioid receptors inhibits AMPA receptor-mediated primary afferent neuro-

\footnotetext{
Received Mar. 13, 1995; revised June 14, 1995; accepted June 20, 1995.

This effort was supported by NIH Grant NS-26352, Grant IBN-9209462 from the National Science Foundation, and the U.S. Department of Agriculture. Correspondence should be addressed to $M$. Randic at the above address.

aPermanent address: Shanghai Institute of Physiology, Chinese Academy of Sciences, 320 Yue-Yang Road, Shanghai 200031, China.

'Present address: Department of Ophthalmology, Faculty of Medicine, University of British Columbia, 2550 Willow Street, Vancouver, BC V5Z 3N9, Canada.

Copyright (C) 1995 Society for Neuroscience $\quad 0270-6474 / 95 / 156809-18 \$ 05.00 / 0$
}

transmission in the substantia gelatinosa of the young rat spinal cord. This effect may mediate the ability of $k$-receptor agonists to produce antinociception.

[Key words: rat spinal cord, substantia gelatinosa, $\kappa-$ opioid receptor, dynorphin, excitatory postsynaptic potential, intracellular recording]

The substantia gelatinosa (SG), lamina 2 of the gray matter of the dorsal horn (DII) of the spinal cord (Rexed, 1952) is the preferential site of termination of small-diameter primary afferent fibers that respond to noxious stimuli (Kumazawa and Perl, 1978; Light and Perl, 1979; Sugiura et al., 1986, 1989; Yoshimura and Jessell, 1989, 1990). This area has been regarded as an important site for the processing of information related to the transmission and modulation of sensory signals including pain (Kumazawa and Perl, 1978; Light et al., 1979; Cervero and Iggo, 1980; Fitzgerald, 1981; Brown, 1982; Rustioni and Weinberg, 1989). The spinal DH, including SG, contains both endogenous opioid peptides derived from proopiomelanocortin, preproenkephalin and preprodynorphin (Miller and Seybold, 1987, 1989; Simon, 1991), and at least three subtypes ( $\mu, \delta$, and $\kappa$ ) of the opioid receptors, which are present both on the primary sensory and DH neurons (Atweh and Kuhar, 1977; Fields et al., 1980; Slater and Patel, 1983; Morris and Herz, 1987; Allerton et al., 1989; Arvidsson et al., 1995a,b). In ligand binding studies, the highly selective arylacetamide ligand ${ }^{3} \mathrm{H}$ U-69,593 has revealed in both rat (Allerton et al., 1989; James et al., 1990) and dog (Hunter et al., 1989) spinal cords a small population of wellcharacterized $\kappa$ receptors in adult animals (however cf. Lahti et al., 1985), with a significantly higher density being observed in young rats. It is possible that these sites represent only a subpopulation of $\kappa_{1}$-receptors, since other distinct $\kappa$-sublypes $\left(\kappa_{2}\right.$, $\kappa_{3}$ ) have been proposed (Attali et al., 1982; Zukin et al., 1988; Clark et al., 1989). A substantial proportion of the $k$-receptors are postsynaptic since about half remain after dorsal rhizotomy (Besse et al., 1990). Functional studies made in adult spinal cord support the involvement of $\mu$ and $\delta$ opioid receptors in spinal antinociception (Yaksh, 1993). However, the cellular mechanism(s) and the role of $\kappa$-opioid receptors and dynorphin peptides in the regulation of sensory information, including pain at the spinal levels, remains controversial (Millan, 1990; Coderre et al., 1993; Duggan and Fleetwood-Walker, 1993).

The opioid peptide dynorphin $\mathrm{A}_{1-17}$ (H-Tyr-Gly-Gly-Phe-LeuArg-Arg-Ile-Arg-Pro-Lys-Leu-Lys-Trp-Asp-Asn-Gln-OH) (dynorphin) is thought to be the endogenous ligand for the $\kappa$ opioid receptors (Chavkin et al., 1982; James et al., 1984; Stevens and Yaksh, 1986; Nock et al., 1990). High frequency electrical stimulation of unmyelinated primary afferent fibers or peripheral nerves in rats and cats has been shown to cause a release of 
dynorphin in DH laminae associated with nociceptive processing (Nyberg et al., 1983; Yaksh et al., 1983; Hutchison et al., 1990). In vivo studies indicated that the activation of $\kappa$-opioid receptors produces generally inhibitory effects on spinal DH neurons (Willcockson et al., 1986; Knox and Dickenson, 1987; Fleetwood-Walker et al., 1988; Hope et all, 1990; Hylden et al., 1991), although excitatory effects were also observed (Willcockson et al., 1986; Knox and Dickenson, 1987; Hylden et al., 1991).

Both the presynaptic and postsynaptic sites of $\kappa$-opioid action have been reported. Presynaptically dynorphin inhibits voltagedependent calcium current in cultured dorsal root ganglion cells (Macdonald and Werz, 1986; Gross and Macdonald, 1987; Bean, 1989); postsynaptically $\mathrm{K}$-opioids increase $\mathrm{K}^{+}$-conductance of SG neurons (Grudt and Williams, 1993) and decrease $\mathrm{Ca}^{2+}$-conductance (Bean, 1989) of DH neurons. In addition, dynorphin depresses or enhances the responses to glutamate and its analogs (Willcockson et al., 1986; Cerne et al., 1995; Kolaj et al., 1995). At the molecular level activation of $\kappa$-opioid receptors leads to activation of G-proteins (Cox, 1993), that can act directly on voltage-dependent ion channels (Moises et al., 1994), or can produce their effects through the involvement of second messenger systems (Childers, 1993). к-Opioid agonists have been shown to inhibit the adenylate cyclase through the action of pertussis toxin-sensitive G-proteins (Attali et al., 1989; Lawrence and Bidlack, 1993; Ingram and Williams, 1994) and they can inhibit G-protein coupled phospholipase C (Misawa et al., 1990; Jin et al., 1994).

In the present study, the effects of dynorphin $A_{1-17}$ and $\mathbf{a} \mathbf{K}_{1-}$ receptor preferring ligand U-69,593 (Lahti et al., 1985; Nock et al., 1990) on the primary afferent-evoked monosynaptic and polysynaptic excitatory postsynaptic potentials (EPSPs) and the passive membrane properties of the SG neurons were examined by intracellular recordings in the transverse spinal cord slice preparation obtained from young rats. Dynorphin $A_{1-17}$ and U-69,593 caused dual modulation of the peak amplitude of presumed monosynaptic AMPA receptor-mediated EPSPs, decreasing synaptic potentials at nanomolar concentrations and increasing EPSPs at micromolar concentrations. The pharmacological specificity of this effect was demonstrated using the $\kappa_{1}$ receptor antagonist norbinaltorphimine (Porthogese et al., 1987; Takemori et al., 1988). In addition, our results indicate that inhibition of a G-protein-coupled adenylate cyclase/cAMP-dependent protein kinase system may mediate the depressant effect of dynorphin $A_{1-17}$ on synaptic response.

Some of the data have appeared in a preliminary form as an abstract (Kojić et al., 1994).

\section{Materials and Methods}

Slice preparation and electrophysiological recording conditions. Standard procedures for preparing and maintaining spinal cord slices from Sprague-Dawley rats, of either sex aged between 15 and $27 \mathrm{~d}$, were used (Murase and Randić, 1983; Randić et al., 1993). Transverse lumbar spinal cord slices $400-500 \mu \mathrm{m}$ thick with attached dorsal root were cut in an oxygenated $\left(95 \% \mathrm{O}_{2} .5 \% \mathrm{CO}_{2}\right)$ Krebs-bicarbonate solution $\left(4^{\circ} \mathrm{C}\right)$ on a vibratome and placed in a holding chamber $\left(34-35^{\circ} \mathrm{C}\right)$ to recover for at least $1 \mathrm{hr}$. A single slice was then transferred to the recording chamber (volume of $1.0 \mathrm{ml}$ ) and continuously perfused with Krebsbicarbonate solution at a rate of about $3 \mathrm{ml} / \mathrm{min}$. The superfusing medium contained (in $\mathrm{mM}$ ): $\mathrm{NaCl}, 124 ; \mathrm{KCl}, 1.9 ; \mathrm{KH}_{2} \mathrm{PO}_{4}, 1.2 ; \mathrm{CaCl}_{2}, 2.4$;

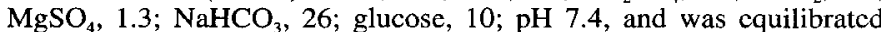
with $95 \% \mathrm{O}_{2}, 5 \% \mathrm{CO}_{2}$. To study primarily AMPA receptor-mediated EPSPs, in some experiments the solution contained strychnine $(2 \mu \mathrm{M})$, bicuculline $(10 \mu \mathrm{M})$ and D-2-amino-5-phosphonovaleric acid (D-APV, $50 \mu \mathrm{M})$ to block glycinergic and GABA-ergic inhibitory synaptic re- sponses, as well as NMDA-component of excitatory synaptic transmission. Experiments were done at a temperature of $34-35^{\circ} \mathrm{C}$. Substantia gelatinosa (SG) neurons were identified by their location in the spinal DH. When viewed under a dissecting microscope at a magnification of $10-40 \times$ with transmitted illumination, the SG was distinguishable as a translucent bend in the superficial $\mathrm{DH}$, although it was difficult to discern with certainty the border hetween laminae I and II. Conventional intracellular recordings were made from SG neurons with electrodes filled with $4 \mathrm{M}$ potassium acetate (DC resistance: $120-160 \mathrm{M} \Omega$ ). Most recordings were obtained from cells with a stable resting-membranc potential and with overshooting action potentials $(78.5 \pm 1.8 \mathrm{mV}, n=$ 81). However, spontaneous firing neurons were also occasionally apparent. In these cases, spontaneous action potentials were abolished by passing sufficient direct hyperpolarizing current through the recording electrode to hold the cell membrane potential negative to the threshold for action potential generation $(-65$ to $-80 \mathrm{mV})$ using the active bridge circuit of the preamplifier (Axoclamp 2A). Bridge balance was monitored throughout experiments and corrected when necessary. Input resistance was measured by passing hyperpolarizing current pulses $(0.05$ $0.2 \mathrm{nA}$ ) across the cell membrane and measuring the voltage deflections produced. The current values were of sufficient duration (120200 msec) to fully charge the membrane capacitance. Monosynaptic and polysynaptic EPSPs in SG neurons were evoked by orthodromic electrical stimulation of primary afferent fibers with a bipolar platinum wire electrodes positioned on the ipsilateral lumbar dorsal root (L3-L6). The dorsal root had a length of $5-15 \mathrm{~mm}$, but when a dorsal root ganglion was preserved up to $27 \mathrm{~mm}$. Single shocks at a fixed suprathreshold strength $(0.01-0.5 \mathrm{msec}$ pulses, $2-40 \mathrm{~V})$, repeated at 2 min intervals, were given through a stimulating electrode during control (10-20 min) period, and during $(10 \mathrm{~min})$ and the $30-60 \mathrm{~min}$ period after bath administration of drugs. Stimulus parameters were optimized to yield depolarization of $5-15 \mathrm{mV}$ in amplitude. EPSPs had to be relatively stable ( $\leq 10 \%$ change in amplitude) for $10-20 \mathrm{~min}$ prior to the addition of any drugs. The stimulus intensity necessary to activate $A \delta$ and $C$ fibers and the afferent fiber conduction velocity were determined by extracellular recording of compound action potentials from longitudinal spinal slicedorsal root-dorsal root ganglia preparations in the previous experiments (Kangrga and Randić, 1991). The minimum stimulus intensities and durations used to activate $A \delta$ and $C$ fibers were $3 \mathrm{~V} / 0.1 \mathrm{msec}$ and 5 $\mathrm{V} / 0.5 \mathrm{msec}$ respectively. The conduction velocity of fibers that were responsible for the monosynaptic response was calculated from the latency of evoked EPSPs and the distance from the stimulating electrode to the recording site. Stimulation of dorsal roots led to generation of an EPSP. With small stimulus strength this EPSP was graded in amplitude, had a fixed latency and monophasic decay. As the stimulus strength was increased, however, a later slow polysynaptic component was apparent. In order to discriminate between monosynaptic and polysynaptic EPSPs two experiments were carried out. (1) Identification of the A $\delta$ fiberevoked EPSPs as monosynaptic was based on their constant latencies and absence of failures with a repetitive stimulation at frequency of 10 $\mathrm{Hz}$ (Randić et al., 1993). (2) The latency of these EPSPs remained constant in the presence of a high concentration of divalent cations ( 4 $\mathrm{mM} \mathrm{Ca}{ }^{2+}, 8 \mathrm{mM} \mathrm{Mg}^{2+}$ ), the procedure that has been shown to suppress polysynaptic EPSPs (Jahr and Jessell, 1985). These findings contrast with the properties of DR-evoked polysynaptic EPSPs. The presumably polysynaptic EPSPs had variable latencies and showed failures with high frequency stimulation and with the external solution containing high divalent cation concentrations. Moreover, the shapes and amplitudes of polysynaptic EPSPs were variable in different trials when dorsal roots were stimulated at a constant intensity.

Two different procedures were used to study the effects of $\kappa$-opioids on electrically evoked EPSPs without interference from action potentials. The cell membrane potential was adjusted to a hyperpolarizing level by passing a DC-current through the recording electrode. Alternatively the primary afferents were stimulated during a hyperpolarizing step of membrane potential at a time when the membrane potential was stable and the decay of membrane charging was negligible. In any given cell the membrane potential was held within a $1-3 \mathrm{mV}$ range. An $\mathrm{Ax}$ oclamp 2A (Axon Instruments) was used to record data; Digidata 1200 system with pCLAMP (version 5.5 and 6) software (Axon Instruments) was used for acquisition and analysis. A DC pen-recorder (Gould 2600S) was used to record membrane potentials continuously. Each slice was exposed to between one and three applications of dynorphin $A_{1-17}, U-50,488 \mathrm{H}$ and $U-69,593$ alone or in combination with the $\kappa-$ opioid receptor antagonist, nor-binaltorphimine (nor-BNI). The $\kappa$-opioid 
receptor agonists were applied in the perfusate for $10 \mathrm{~min}$ in the absence or continuous presence of the antagonist. In experiments with nor-BNI, slices were washed for $25-45 \mathrm{~min}$ between drug applications to ensure sufficient washout of opioid effects. The magnitude of $\kappa$-opioid effects in any individual cell were determined by comparing the averaged peak amplitude of three consecutive EPSPs evoked immediately prior to drug application $\left(V_{\text {control }}\right)$ to the peak amplitude of a single EPSP measured at the time of maximal change induced by $\mathrm{\kappa}$-opioids $\left(V_{\text {treatmen }}\right) . V_{\text {treatment }}$ was typically determined 6-10 min after the onset of $\mathrm{K}$-opioid application and was expressed as percentage of control: $V_{\text {tearmen }} / V_{\text {conrol }} \times 100$. Moreover, two additional measures of synaptic responses, EPSP slope and area, were used. We first tested the stability of the synaptic and passive membranc propertics of SG ncurons in slices over a period of 10-20 min and next examined the changes in these properties as a result of $\kappa$-opioid treatment. Over a recording period of $1-2 \mathrm{hr}$, resting membrane potential, input resistance and the peak amplitude of the EPSP did not change significantly in SG neurons of slices obtained from young rats. All values are expressed as means \pm SEM. Statistical significance of data $(P \leq 0.05)$ has been assessed relative to control responses by use of either a paired or unpaired $t$ tests, as appropriate.

Application of chemicals. Drugs were dissolved in oxygenated Krebsbicarbonate solution and applied to the slices in known concentrations by addition to the superfusing medium. Drug-containing solution entered the recording chamber within $30-45 \mathrm{sec}$ of changing solutions, with complete exchange occurring within $3 \mathrm{~min}$. Drugs were applied for sufficient duration to ensure maximum effects. Only one cell in a slice was subject to one trial with $\kappa$-opioids, the exception bcing the experiments using opioid receptor antagonists where each cell was subjected to two or three trials. Chemicals used and their sources were as follows: adenosine-3',5'-cyclic monophospho-thioate, Rp-Isomer, triethylammonium salt (Rp-cAMPS, Calbiochem); $(5 \alpha, 7 \alpha, 8 \beta)-(+)-N-$ methyl- $N$-[7-(1-pyrrolidinyl)-1-oxaspiro(4,5)dec-8-yl]benzeneacetamide (U-69,593) (Research Biochemicals International, RBI, Natick, MA), D-2-amino-5-phosphonovaleric acid (D-APV; RBI), bicuculline methiodide (Sigma), CTAP (H-D-Phe-Cys-Tyr-D-Trp-Arg-Thr-Pen-Thr-NH, Multiple Peptide System, San Diego, CA); 6-cyano-7-nitroquinoxaline2,3-dione (CNQX) (Cambridge Research Biochemicals, CRB, Wilmington, DE; Tokris, Bristol, United Kingdom); dynorphin $\mathrm{A}_{1-17}$ (prodynorphin 209-225, porcine; CRB, Peninsula, Belmont, CA and RBI), $\mathrm{N}, \mathrm{N}$-dially-Tyr-Aib-Aib-Phe-Leu (ICI 174,864, CRB); naloxone $\mathrm{HCl}$ (RBI, Sigma); naltrindole hydrochloride (RBI); nor-binaltorphiminc 2 $\mathrm{HCl}$ (nor-BNI) (RBI); strychnine hydrochloride (Sigma), tetrodotoxin (TTX; Sigma), trans- $( \pm)-3,4$-dichloro- $N$-methyl- $N$-[2-(1-pyrrolidinyl)cyclohexyl] benzeneacetamide methane sulfonate $(\mathrm{U}-50,488 \mathrm{H})(\mathrm{RBI})$. Stock solutions of U69,593 of $1 \mathrm{mM}$ were made in $0.1 \mathrm{~N} \mathrm{HCl}$ and then frozen in aliquots to be used in single experiments. The aliquots were diluted in perfusing solution before administration.

\section{Results}

Stable intracellular recordings of up to $5 \mathrm{hr}$ were obtained from 191 SG ncurons in the rat spinal cord slice. The average resting membrane potential of these neurons was $-71.9 \pm 0.5 \mathrm{mV}$ (mean $\pm \mathrm{SEM}$ ) and the input resistance $201.2 \pm 9.1 \mathrm{M} \Omega$ in agreement with previous results (Yoshimura and Jessell, 1990; Randić, et al., 1993).

\section{Effects of dynorphin on membrane potential and input resistance of $S G$ neurons}

When recording at resting membrane potential, bath application of dynorphin (0.01-1 $\mu \mathrm{M}$ for $10 \mathrm{~min}$ ) caused two distinct effects: a slow reversible membrane hyperpolarization in eleven (52\%) and a depolarization in six (29\%) of $21 \mathrm{SG}$ neurons (Fig. 1A,B). The hyperpolarization had an average onset latency of $2.9 \pm 0.5$ $\min$ and a duration of $11.1 \pm 1.4 \mathrm{~min}$. The response was maximal at $6.5 \pm 0.8 \mathrm{~min}$ after the start of application of dynorphin, and it averaged $-4.0 \pm 0.8 \mathrm{mV}$. The hyperpolarization was associated with a variable but statistically not significant $(P>$ $0.05 ; n=11$ ) changes in membrane input resistance (decrease to $84.3 \% \pm 3.3$ of control, $n=4 / 11$; increase to $112.3 \% \pm 2.7$, $n=3 / 11$; however, for all cells $98.2 \% \pm 3.2, n=11$ ). The
A
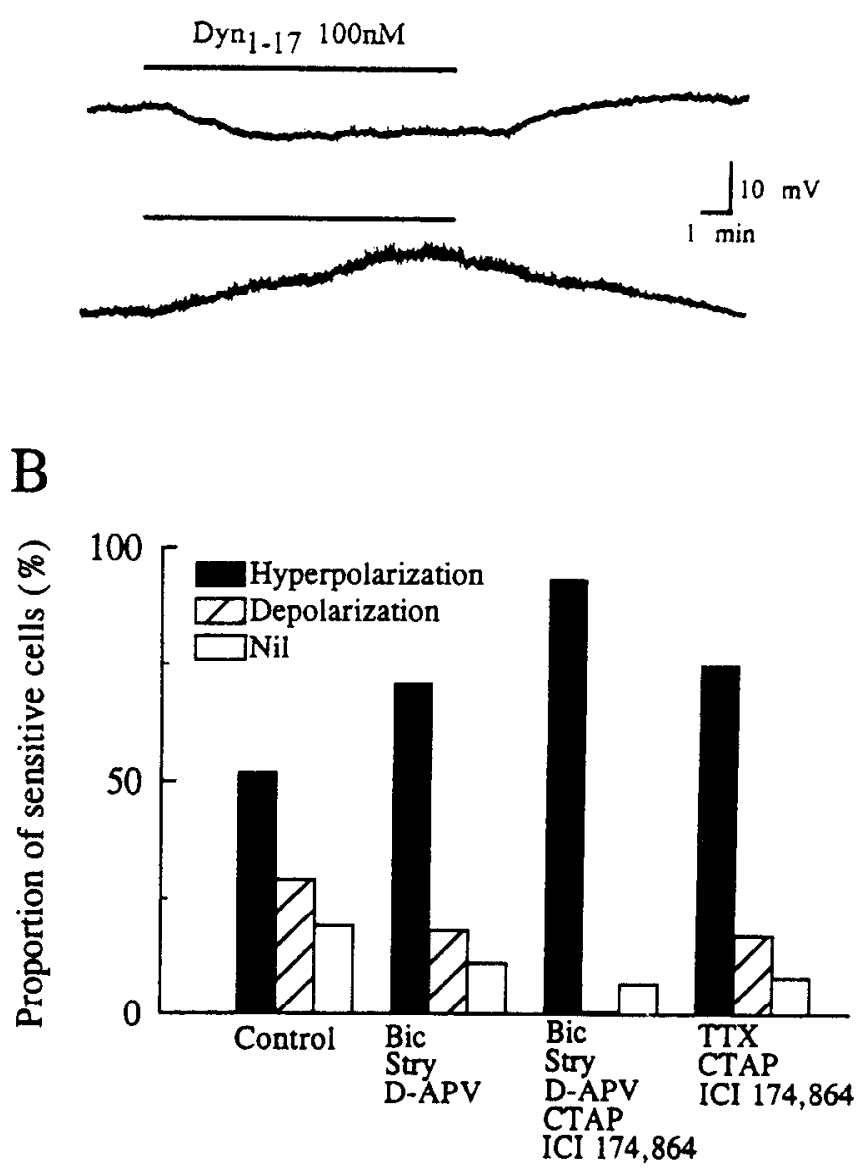

Figure 1. Effects of dynorphin $\mathrm{A}_{1-17}$ on the membrane potential of SG neurons. $A$, Sample records of the hyperpolarizing (top) and depolarizing (bottom) responses intracellularly recorded from two differcnt $S G$ neurons to $10 \mathrm{~min}$ bath-application of $100 \mathrm{~mm}$ dynorphin $A_{1-17}$ (bar). Both responses recovered following wash-out of dynorphin. $B$, Summarized data showing the proportion of SG neurons that responded with either hyperpolarization (solid bars) or depolarization (hatched bars) or no effect (open bars) to the application of dynorphin $A_{1-17}(0.01-1 \mu \mathrm{M})$ in the different perfusion media: (1) control solution (Control, $n=21$ ); (2) bicuculline (Bic, $10 \mu \mathrm{M})+$ strychnine (Stry, $2 \mu \mathrm{M})+\mathrm{D}-2$-amino5-phosphonovaleric acid $(D-A P V, 50 \mu \mathrm{M})(n=17)$; (3) Bic $(10 \mu \mathrm{M})+$ Stry $(2 \mu \mathrm{M})+$ D-APV $(50 \mu \mathrm{M})+$ CTAP $(100 \mathrm{nM})+$ ICI $174,864(100$ nM) $(n=15)$; (4) TTX $(500 \mathrm{nM})+$ CTAP $(100 \mathrm{nM})+$ ICI 174,864 $(100 \mathrm{nM})(n=12)$. Note that hyperpolarization was almost exclusively present on application of dynorphin $A_{1-17}$ after blockade of $\mathrm{GABA}_{\mathrm{A}}$-, glycine-, NMDA-, $\mu$-, and $\delta$-opioid receptors. A:top, $V_{m}=-62 \mathrm{mV}$, $22 \mathrm{~d}$ old rat; bottom, $V_{m}=-74 \mathrm{mV}, 17 \mathrm{~d}$ old rat. $B, V_{m}=-62$ to -82 $\mathrm{mV}, 15-27 \mathrm{~d}$ old rats.

second kind of response to dynorphin was a slow depolarization accompanied by a slight increase $(n=4 / 6)$ in membrane input resistance $(107.5 \% \pm 4.9$ of control, $n=6)$. The response had a latency of onset of $1.8 \pm 0.5 \mathrm{~min}$, and was associated with increased excitability of the cell, as reflected by the generation of spontaneous action potentials. The depolarization reached maximum amplitude in $6.0 \pm 1.2 \mathrm{~min}$; the amplitude was 8.0 $13.9 \mathrm{mV}$ and the duration of $14.4 \pm 6.7 \mathrm{~min}$. The threshold concentration for evoking the hyperpolarizing and depolarizing response during superfusion with dynorphin was $10 \mathrm{nM}$. No desensitization of either hyperpolarizing or depolarizing response 
Figure 2. Reversal potential of $\mathrm{A} \delta$ primary afferent fiber-evoked monosynaptic EPSPs and antagonism by CNQX and D-APV. A, Reversal potential of presumed monosynaptic A $\delta$-fiber-mediated EPSP recorded intracellularly with a 4 M Cs acetate-filled microelectrode at six different membrane potentials from a dorsal horn neuron in response to dorsal root stimulation. Stimulation of L4 dorsal root $(3 \mathrm{~V}, 20$ $\mu \mathrm{sec}, 0.7 \mathrm{~Hz}$ ) elicited constant latency EPSP. The EPSP decreased in size and reversed its polarity with membrane depolarization. $B$, Relationship between the peak amplitude of EPSP and membrane potential. The reversal potential of the EPSP is around $0 \mathrm{mV}$. $C$, Depression of A $\delta$-fiber-evoked EPSP by $10 \mu \mathrm{M}$ CNQX and almost complete blockade by $10 \mu \mathrm{M}$ CNQX $+50 \mu \mathrm{M}$ D-APV. $A$ and $B, 26 \mathrm{~d}$ old rat. $C, V_{m}$ $=-79 \mathrm{mV}, 24 \mathrm{~d}$ old rat.
A

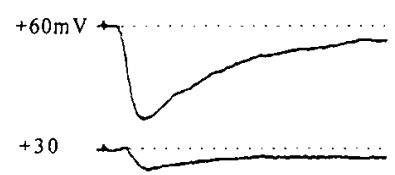

$\div 10$

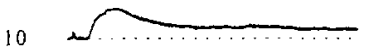

$-10$
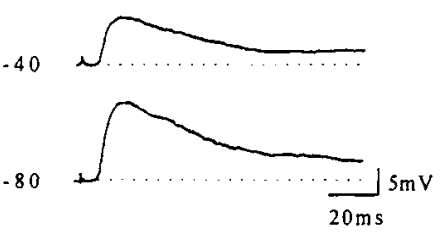

B

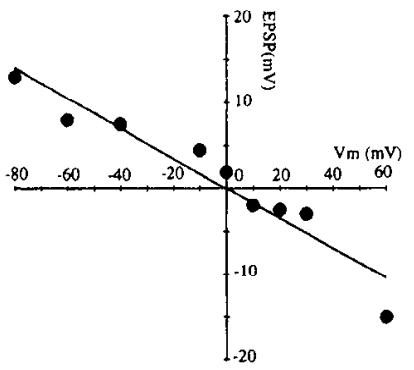

$\mathrm{C}$

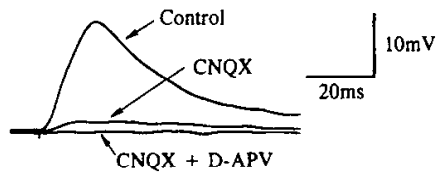

was observed during 10 min superfusion with dynorphin (10 $\mathrm{nM}$ to $1 \mu \mathrm{M}$ ).

\section{Involvement of GABA and glycine in the depolarizing action of dynorphin}

Because the inhibitory interneurons have been implicated as a primary target of opioid action in hippocampus (Zieglgänsberger et al., 1979; Neumaier et al., 1988) and rat spinal DH (Magnuson and Dickenson, 1991), experiments were next carried out with bicuculline and strychnine to assess the possible involvement of GABA and/or glycine in the mediation of the dynorphin-induced membrane effects. When bicuculline methiodide $(10 \mu \mathrm{M})$, a GA$\mathrm{BA}_{\mathrm{A}}$ receptor antagonist, and strychnine $(2 \mu \mathrm{M})$, a glycine receptor antagonist, were added to the bathing solution containing $50 \mu \mathrm{M}$ D-APV, the NMDA receptor antagonist, 12 of $17(71 \%)$ SG neurons responded to dynorphin (10 nM to $1 \mu \mathrm{M})$ with hyperpolarization $(-4.9 \pm 0.9 \mathrm{mV})$, whereas 3 of 17 cells $(18 \%)$

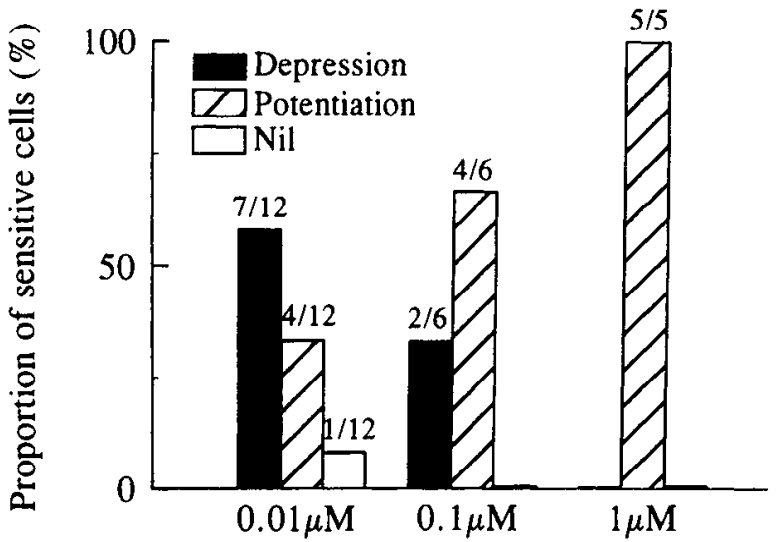

Figure 3. Proportion of sensitive SG neurons showing depression or potentiation of primary afferent fibers-evoked EPSPs by dynorphin $A_{1}$. ${ }_{17}$. The graph shows the proportion of SG neurons that responded to 10 min application of different concentrations of dynorphin $A_{1-17}(0.01-1$ $\mu \mathrm{M})$ with either depression (solid bars) or potentiation (hatched bars) of primary affcrent fiber-evoked EPSPs, or were not affected (open bars). Note that both depression and potentiation of EPSPs were present at lower concentrations of dynorphin $(0.01 \mu \mathrm{M}, n=12 ; 0.1 \mu \mathrm{M}, n=$ 6 ), whereas higher concentration ( $1 \mu \mathrm{M}, n=5)$ increased EPSPs in all the cells examined. $V_{m}=-62$ to $-82 \mathrm{mV}, 15-27 \mathrm{~d}$ old rats. gave a depolarizing $(3.3 \pm 0.7 \mathrm{mV})$ response (Fig. $1 B$ ). It appears therefore, that the presumed blockade of GABA-ergic and glycinergic transmission reduced the proportion of cells responding to dynorphin with depolarization and increased the number of hyperpolarized cells.

\section{Pharmacological profile of the dynorphin actions on membrane potential.}

To characterize the spinal opioid receptor subtype responsible for the dynorphin-induced hyperpolarization and depolarization in SG neurons, we next examined the actions of a claimed selective $\kappa_{1}$-opioid receptor antagonist norbinaltorphimine (norBNI) (Portoghese et al., 1987; Takemori et al., 1988). Bathapplication of nor-BNI (100 nM) consistently and reversibly reduced or blocked the dynorphin-induced hyperpolarization $(n=$ 2) and depolarization $(n=3)$ in slices perfused with Krebsbicarbonate solution, and also the hyperpolarization $(n=3)$ in the presence of blockade of NMDA, GABA ${ }_{\mathrm{A}}$ and glycine receptors. Nor-BNI, in the concentration used here (100 nM), did not alter the resting membrane potential $(-0.5 \pm 0.9 \mathrm{mV}, n=$ 8) or input resistance $(98.5 \% \pm 3.7, n=12)$ of SG neurons.

Although dynorphin $A_{1-17}$ is an endogenous opioid thought to act at $\kappa$-opioid receptors, it has also affinity for the $\mu$-site and somewhat less for the $\delta$-site (Corbett et al., 1993). Moreover, there is evidence for the higher densities of $\mu$ - and $\delta$-receptors relative to $\kappa$-receptors in the spinal $\mathrm{DH}$ (Stevens et al., 1991). To exclude the possibility that dynorphin might activate $\mu$ - and $\delta$-sites, the membrane response of $S G$ cells to dynorphin was examined in slices superfused with a solution containing, besides bicuculline $(10 \mu \mathrm{M})$, strychnine $(2 \mu \mathrm{M})$ and D-APV $(50 \mu \mathrm{M})$, also two highly selective $\mu$ - and $\delta$-opioid receptors blocking agents, CTAP (10-100 nM) (Pelton et al., 1985; Kazmierski et al., 1988) and ICI 174,864 (10-100 nM) (Cotton et al., 1984). Dynorphin $(10 \mathrm{nM})$ hyperpolarized $(-5.5 \pm 1.2 \mathrm{mV}) 14$ of 15 SG cells examined (Fig. $1 B$ ), whereas one cell was not affected. A slow hyperpolarization was accompanied by a decreased $(77.8 \% \pm 7.7 ; n=2 / 6)$ or an increased $(113.7 \% \pm 2.3, n=$ 3/6) input resistance (however, for all cells: $102.0 \% \pm 5.9, n=$ $6)$. In addition, $U-69,593$, the $\kappa_{1}$-opoiod receptor preferring ligand (Lahti et al., 1985), hyperpolarized $(-5.1 \pm 0.9 \mathrm{mV}) 10$ of $12 \mathrm{SG}$ cells. This result differs from the depolarizing effect 

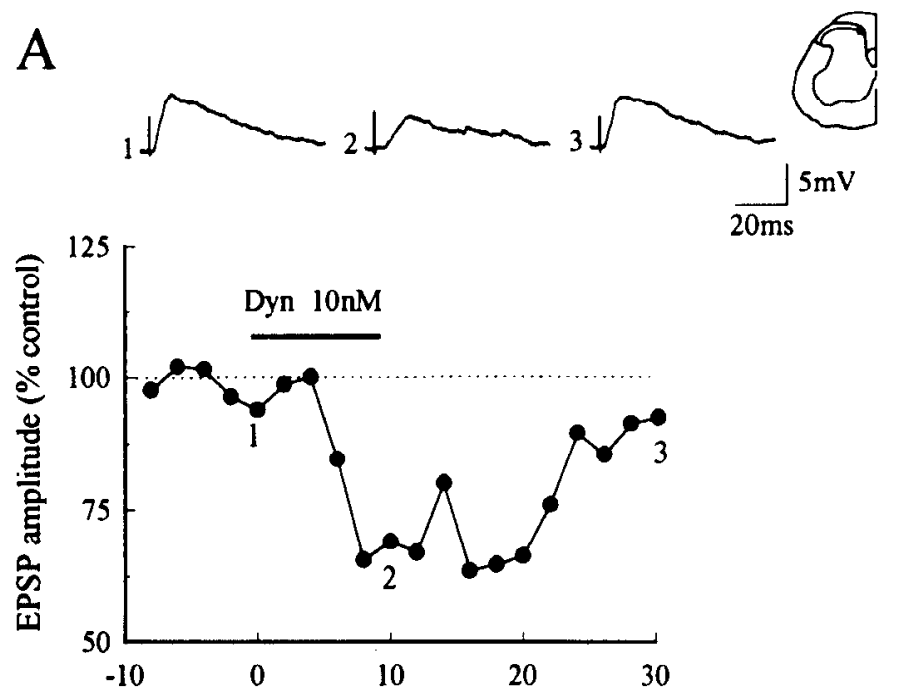

B
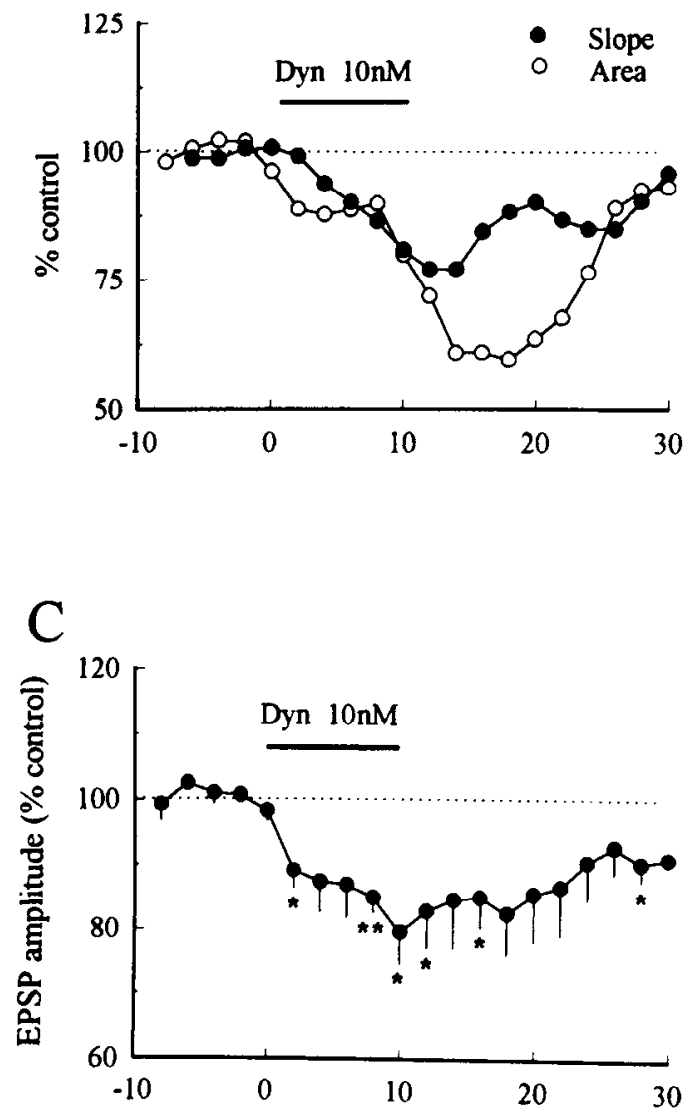

Time $(\mathrm{min})$

Figure 4. Depression of A $\delta$-primary afferent fiber-evoked EPSPs by dynorphin $\mathrm{A}_{1-17}$. A, The graph shows the time course of changes in the peak amplitude of EPSPs (solid symbols), recorded intracellularly at 2 min intervals from a SG neuron (inset) in response to electrical stimulation $(12 \mathrm{~V}, 0.05 \mathrm{msec})$ of a lumbar dorsal root. Above the graph are displayed individual, apparently monosynaptic EPSPs taken before (trace 1), during (trace 2) and $20 \mathrm{~min}$ (trace 3) after the removal of dynorphin $(10 \mathrm{nM})$. In this and all subsequent figures, the solid bar above the graph indicates the time at which drug application occurred. Experiments were run at a constant membrane potential by applying
$(4.3 \pm 0.9 \mathrm{mV})$ observed in 3 of 6 cells superfused with Krebsbicarbonate solution. The hyperpolarizing effect of dynorphin $(10 \mathrm{nM})$ was fully reversed by nor-BNI $(10 \mathrm{nM}, n=3)$ and partial recovery from this inhibition was observed after 20-30 min washout. Nor-BNI, by itself in this medium, caused a small hyperpolarization $(-3.5 \pm 0.5 \mathrm{mV})$ associated with a decrease in input resistance $(91.9 \% \pm 1.3)$ in 4 of $6 \mathrm{SG}$ neurons.

To determine if the hyperpolarizing response to dynorphin was mediated by direct activation of postsynaptic $\kappa$-opioid receptors of SG neurons, we examined the effect of dynorphin on membrane potential and input resistance in the presence of CTAP (10-100 nM) and ICI 174,864 (10-100 nM), and when synaptic transmission was eliminated by the $\mathrm{Na}^{+}$channel blocker tetrodotoxin (TTX, $0.5 \mu \mathrm{M}, n=12$ ). Under these conditions the response of $\mathrm{SG}$ neurons to $10 \mathrm{nM}$ dynorphin was hyperpolarization $(-4.2 \pm 0.8 \mathrm{mV}, n=9 / 12)$, and this effect was accompanied by a reduction in the input resistance (to $77.3 \% \pm$ $1.9 ; n=6 / 7$ ). In comparison, the depolarizing response was greatly reduced $(n=2)$ or abolished $(n=1)$ in this medium. Our finding that the dynorphin-induced hyperpolarization persisted in the presence of $\mu$ - and $\delta$-blocking agents and when synaptic transmission was blocked by TTX strongly suggests a postsynaptic $\kappa_{1}$-opioid receptor site for the hyperpolarizing action of dynorphin. The fact that TTX inhibits the depolarizing response to dynorphin suggests a presynaptic site for this action, perhaps through inhibition of GABA-ergic inhibitory interneuron (Wang and Randić, 1994).

\section{Dual modulation of excitatory transmission by dynorphin in the substantia gelatinosa}

Electrical stimulation of the primary afferent fibers in a dorsal root elicited monosynaptic and/or polysynaptic EPSPs in $75 \%$ and $25 \%$ of SG cells, respectively, in agreement with previous observations (Yoshimura and Jessell, 1990; Randić et al., 1993). The reversal potential of A $\delta$ fiber-mediated presumed monosynaptic EPSP (Fig. $2 A$ ) was around $0 \mathrm{mV}$ (Fig. $2 B$ ). The EPSP was almost completely suppressed by $10 \mu \mathrm{M}$ CNQX (Fig. $2 C$ ), the finding suggesting that primary afferent fibers release glutamate, or a related amino acid, and that the synaptic activation of the AMPA/kainate receptors of SG neurons predominantly mediates the A $\delta$ fiber-evoked EPSP (Yoshimura and Jessell 1990; Jiang and Randić, 1991; Randić et al., 1993; Yoshimura and Nishi, 1993).

Bath application of dynorphin $\mathrm{A}_{1-17}(0.01-1 \mu \mathrm{M}$ for $10 \mathrm{~min})$ in a Krebs-bicarbonate solution causes a dual modulation of the primary afferent stimulation-evoked monosynaptic and polysynaptic EPSPs: it decreased and increased synaptic responses at low concentrations (10 $\mathrm{nM})$ and almost exclusively increased EPSPs at high concentrations ( $1 \mu \mathrm{M})$ (Fig. 3). The depression and potentiation of EPSPs was present in the SG cells receiving inputs from either $A \delta$ (Figs. 4, 5) or C-primary afferent fibers (Fig. 6). The reduction in the peak amplitude monosynaptic (to $79.6 \% \pm 4.9$ of control) and polysynaptic EPSPs (to $60.7 \% \pm$

$\leftarrow$

appropriate intracellular current injection during the application of dynorphin, if necessary. $B$, The graph shows the time course of changes in the slope (solid symbols) and area (open symbols) of EPSPs from the same neuron, as shown in $A$. $C$, Summarized data (means $\pm S E M$ ) showing the time course of the depression of EPSPs for 4 SG neurons produced by $10 \mathrm{nM}$ dynorphin. Statistical significance of data is indicated by asterisks: *, $P<0.05 ; * *, P<0.01 . A$ and $B, V_{m}=-73 \mathrm{mV}$, $23 \mathrm{~d}$ old rat. $C, V_{m}=-69$ to $-76 \mathrm{mV}, 18-23 \mathrm{~d}$ old rats. 
A<smiles>CCCCCC</smiles>

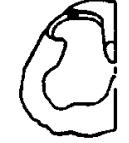

2
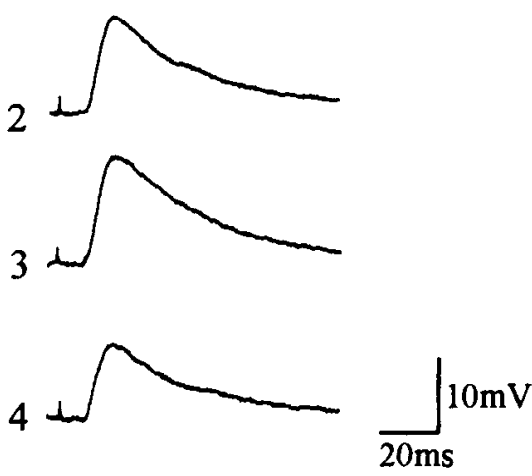

$\mathrm{C}$

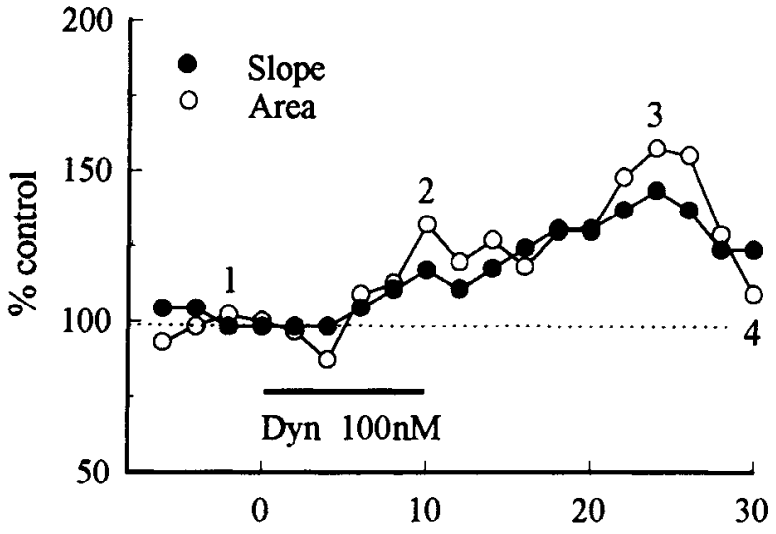

Time (min)
B

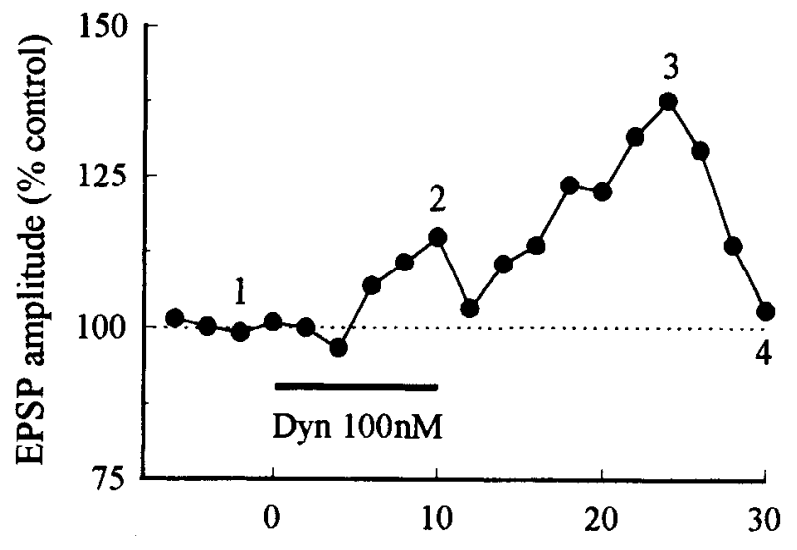

$\mathrm{D}$

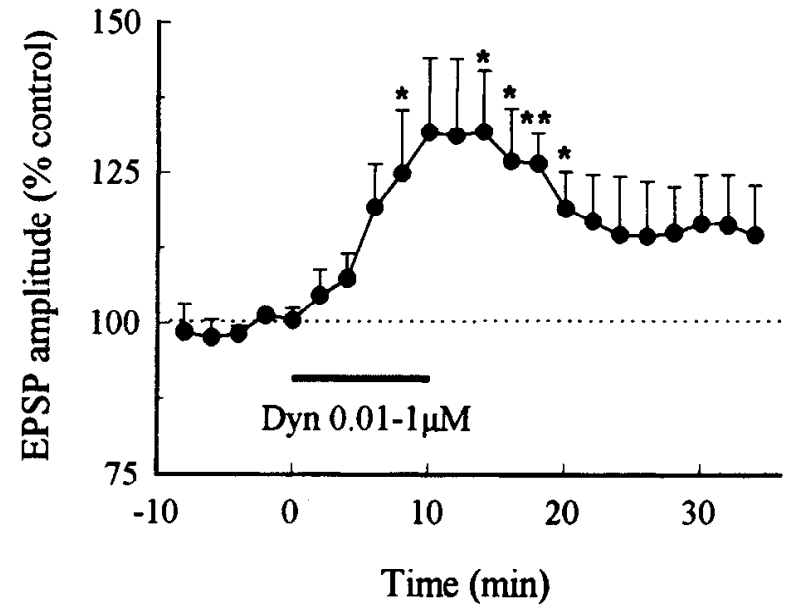

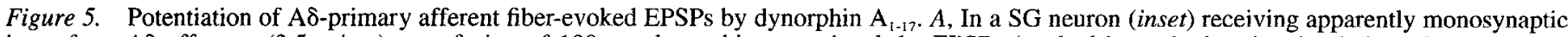
input from AS afferents $(3.5 \mathrm{~m} / \mathrm{sec})$ superfusion of $100 \mathrm{nM}$ dynorphin potentiated the EPSPs (evoked by orthodromic stimulation of L5 DR with electrical pulses of $12 \mathrm{~V}, 0.05 \mathrm{msec}$ ) at $10 \mathrm{~min}$ during (trace 2) and $15 \mathrm{~min}$ after removal of the peptide (trace 3 ). This effect recovered at 20 min (trace 4) on washout. $B$, The graph shows the time course of changes in the peak amplitude of EPSPs. $C$, The graph shows the time course of changes in the slope (solid symbols) and area (open symbols) of EPSPs recorded from the same neuron, as shown in $A$. D. Summarized data showing the time course of the potentiation of EPSPs for 9 SG neurons produced by $10 \mathrm{nM}$ to $1 \mu \mathrm{M}$ dynorphin. Statistical significance of data is indicated by asterisks: *, $P<0.05 ; * *, P<0.01 . A-C, V_{m}--72 \mathrm{mV}, 25 \mathrm{~d}$ old rat. $D, V_{m}=-63$ to $-73 \mathrm{mV}, 19-26 \mathrm{~d}$ old rats.

2.8), caused by dynorphin (10-100 nM) was present in 4 of 13 and 5 of 10 SG cells examined, respectively (Table 1). The inhibition of EPSP amplitude by dynorphin ranged among neurons from $92 \%$ to $50 \%$ of control responses. Ten minutes of dynorphin perfusion was typically sufficient to obtain a maximal effect without the development of desensitization (Fig. 4C). The peak depression had a latency of $5.9 \pm 1.0 \mathrm{~min}(n=9)$ and the effect persisted for 10-30 min after the application of dynorphin was terminated (Fig. 4). A typical depressant effect of $10 \mathrm{nM}$ dynorphin on A $\delta$ fiber-evoked presumed monosynaptic EPSP is illustrated in Figure 4. In this cell, the depression of the EPSP involved a reduction of the peak amplitude of the EPSP (Fig. 4A) and also the slope and area (Fig. $4 B$ ) of the EPSP. The dynorphin-induccd depression of synaptic response was associated with inconsistent change in membrane potential $(-1.4 \pm 1.5$
$\mathrm{mV}, n=8$ ) and a small but statistically insignificant decrease in input resistance (to $84.3 \% \pm 5.3, n=7$; Fig. 1). Moreover, the depression of monosynaptic EPSP was observed in three SG cells in the absence of the dynorphin effects on membrane potential and input resistance.

Besides the depression of synaptic responses, the bath application of dynorphin (0.01-1 $\mu \mathrm{M}$ for $10 \mathrm{~min})$ produced a revcrsible increase of the peak amplitude of monosynaptic (to $129.6 \%$ $\pm 6.8,9 / 13$ cells, Fig. $5 A, B$ ) and polysynaptic EPSPs (to $166.2 \%$ $\pm 31.7,4 / 10$ cells), in $23 \mathrm{SG}$ cells examined (Table 1). The maximal enhancing effect had a latency of $6.3 \pm 0.7 \mathrm{~min}(n=$ 13). The duration of the dynorphin-induced enhancement of the peak amplitude of EPSPs (Fig. $5 B, D$ ) as well as the slope and area (Fig. $5 C$ ), was prolonged and frequently persisted for more than $30 \mathrm{~min}$ (Fig. $5 \mathrm{D}$ ). The enhancing effect of dynorphin was 
A

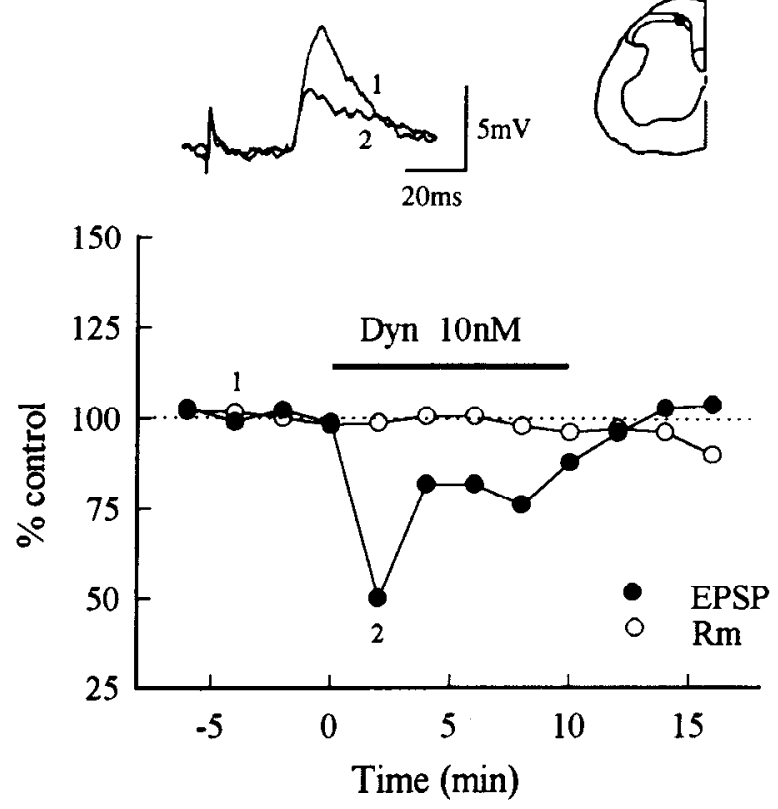

B
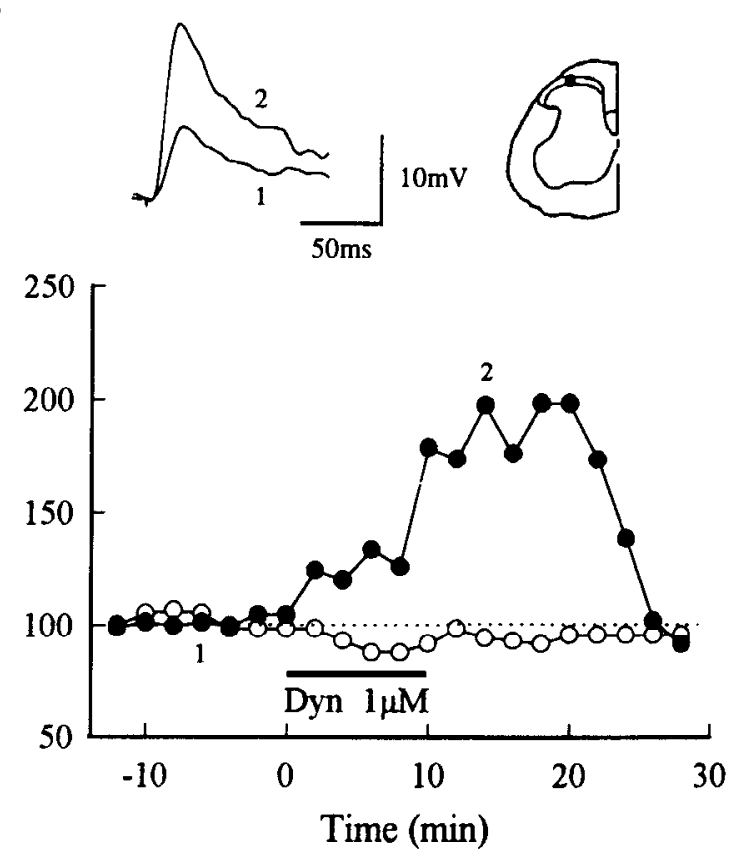

Figure 6. Dual modulation of C-primary afferent fiber-evoked EPSPs by dynorphin $\mathrm{A}_{1-1 \%}$. A, The peak amplitude of the EPSPs (solid symbols), recorded intracellularly from a $S G$ neuron (inset) receiving synaptic input from C-afferents $(0.3 \mathrm{~m} / \mathrm{sec})$, is inhibited by a 10 min application of dynorphin (10 nM, solid bar). EPSPs recorded before (trace 1) and during bath-application of $10 \mathrm{nM}$ dynorphin (trace 2) are superimposed above the graph. $B$, In a different SG neuron (inset) receiving synaptic input from C-afferents $(0.9 \mathrm{~m} / \mathrm{sec})$, dynorphin (1 $\mu \mathrm{M})$ produced potentiation of EPSPs (solid symbols) lasting more than $20 \mathrm{~min}$ after the removal of the peptide. Above the graph are superimposed individual EPSPs taken before (trace 1) and $4 \mathrm{~min}$ (trace 2) after the removal of dynorphin. The membrane input resistance (open symbols) of the neurons in $A$ and $B$ was monitored throughout the experiment. $A, V_{m}=-69 \mathrm{mV}, 19 \mathrm{~d}$ old rat. $B, V_{m}=-71 \mathrm{mV}, 25 \mathrm{~d}$ old rat.

associated with small and inconsistent changes in membrane potential $(1.4 \pm 2.7 \mathrm{mV}, n=12)$ and a small but statistically insignificant increase in input resistance $(111.3 \% \pm 3.5, n=$ 12; Fig. 1).

\section{Pharmacological profile of the dynorphin actions on EPSPS}

To determine the type of the opioid receptor involved in mediating the depression and potentiation of EPSPs by dynorphin, we have used two benzeneacetamide derivatives $\mathrm{U}-50,488 \mathrm{H}$ and U-69,593, the $\kappa_{1}$-receptor preferring ligands (VonVoigtlander et al., 1983; Lahti et al., 1985; Nock et al., 1988, 1990, 1993; Zukin et al., 1988; Rothman et al., 1992), as well as a claimed selective $\kappa_{1}$-opioid receptor antagonist nor-BNI (Portoghese et al., 1987; Takemori et al., 1988). Bath application of 0.01-1 $\mu \mathrm{M}$
$\mathrm{U}-50,488 \mathrm{H}(n=6)$ and $\mathrm{U}-69,593(n=11)$ for 10 min resulted in depression or potentiation of the primary afferent fiber-evoked monosynaptic $(n=13)$ and polysynaptic EPSPs $(n=4)$. The peak amplitude of the monosynaptic EPSP was reduced on average to $80.0 \%$ in 2 of $5 \mathrm{SG}$ neurons by $\mathrm{U}-50,488 \mathrm{H}$, and increased to $155.3 \% \pm 19.4$ in the remaining 3 cells tested. The average reduction of the peak amplitude of the monosynaptic EPSPs by U-69,593 was to $67.0 \% \pm 8.0(n=3 / 8)$ and an increase to $135.8 \% \pm 13.7(5 / 8)$ (Table 2). The U-69,593-induced depression of EPSPs in $5 / 11$ neurons ( $10 \mathrm{nM}$ : to $80.5 \%$ $\pm 6.5 ; 100 \mathrm{nM}$ : to $63.5 \% \pm 12.5 ; 1 \mu \mathrm{M}$ : to $45.0 \%$; Fig. $7 A, B)$ and potentiation in $5 / 11$ ncurons $(10 \mathrm{nM}$ : to $111.0 \% \pm 4.0 ; 1$ $\mu \mathrm{M}$ : to $154.5 \% \pm 28.5$; Fig. $7 C, D)$ and the effects appear to be dose dependent. Both responses to U-69,593 were slow to reach

\section{Table 1. Modulation of primary afferent flber-evoked EPSPs of SG neurons by dynorphin $A_{1-17}$ in different perfusion media}

\begin{tabular}{|c|c|c|c|c|c|c|c|c|}
\hline \multirow[b]{2}{*}{$\begin{array}{l}\text { Perfusing } \\
\text { solution }\end{array}$} & \multicolumn{4}{|c|}{ Monosynaptic EPSP } & \multicolumn{4}{|c|}{ Polysynaptic EPSP } \\
\hline & $n$ & Depression & Potentiation & $\begin{array}{l}\text { No } \\
\text { change }\end{array}$ & $n$ & Depression & Potentiation & $\begin{array}{l}\text { No } \\
\text { change }\end{array}$ \\
\hline Control solution & 13 & $\begin{array}{l}31 \% \\
(79.6 \pm 4.9)^{*}\end{array}$ & $\begin{array}{l}69 \% \\
(129.6 \pm 6.8)^{* *}\end{array}$ & $0 \%$ & 10 & $\begin{array}{l}50 \% \\
(60.7 \pm 2.8)^{* *}\end{array}$ & $\begin{array}{l}40 \% \\
(166.2 \pm 31.7)\end{array}$ & $10 \%$ \\
\hline $\begin{array}{l}\text { Control }+ \text { bicuculline }+ \\
\text { strychnine }+ \text { D-APV }\end{array}$ & 6 & $\begin{array}{l}50 \% \\
(71.7 \pm 12.2)\end{array}$ & $\begin{array}{l}17 \% \\
(157.00)\end{array}$ & $33 \%$ & 13 & $\begin{array}{l}62 \% \\
(69.0 \pm 4.6)^{* *}\end{array}$ & $\begin{array}{l}31 \% \\
(142.0 \pm 17.4)\end{array}$ & $7 \%$ \\
\hline $\begin{array}{l}\text { Control + bicuculline + strychnine }+ \\
\text { D-APV + CTAP + ICI } 174,864\end{array}$ & 19 & $\begin{array}{l}63 \% \\
(79.0 \pm 2.7)^{* *}\end{array}$ & $\begin{array}{l}37 \% \\
(126.7 \pm 9.4)^{*}\end{array}$ & $0 \%$ & 4 & $\begin{array}{l}75 \% \\
(69.7 \pm 3.7)^{*}\end{array}$ & $\begin{array}{l}25 \% \\
(133.0)\end{array}$ & $0 \%$ \\
\hline
\end{tabular}

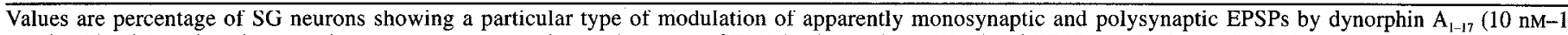

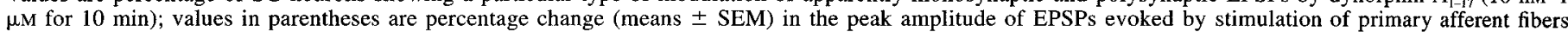

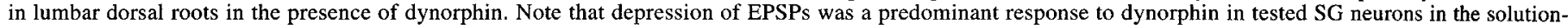

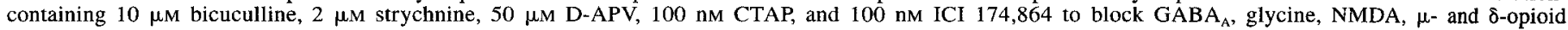
receptors, respectively. Statistical significance of data is indicated by asterisks: $*, P<0.05 ; * *, P<0.01$. 
Table 2. Modulation of primary afferent fiber-evoked EPSPs of SG neurons by U-69,593 in different perfusion media

\begin{tabular}{|c|c|c|c|c|c|c|c|c|}
\hline \multirow[b]{2}{*}{$\begin{array}{l}\text { Perfusing } \\
\text { solution }\end{array}$} & \multicolumn{4}{|c|}{ Monosynaptic EPSP } & \multicolumn{4}{|c|}{ Polysynaptic EPSP } \\
\hline & $n$ & Depression & Potentiation & $\begin{array}{l}\text { No } \\
\text { change }\end{array}$ & $n$ & Depression & Potentiation & $\begin{array}{l}\text { No } \\
\text { change }\end{array}$ \\
\hline Control solution & 8 & $\begin{array}{l}38 \% \\
(67.0 \pm 8.0)^{*}\end{array}$ & $\begin{array}{l}62 \% \\
(135.8 \pm 13.7)\end{array}$ & $0 \%$ & 3 & $\begin{array}{l}67 \% \\
(66.0 \pm 21.0)\end{array}$ & $0 \%$ & $33 \%$ \\
\hline $\begin{array}{l}\text { Control + bicuculline + strychnine + } \\
\text { D-APV + CTAP + ICI 174,864 }\end{array}$ & 11 & $\begin{array}{l}91 \% \\
(64.2 \pm 8.4)^{* *}\end{array}$ & $\begin{array}{l}9 \% \\
(150.0)\end{array}$ & $0 \%$ & 7 & $\begin{array}{l}72 \% \\
(66.0 \pm 6.1)^{* *}\end{array}$ & $\begin{array}{l}14 \% \\
(112.0)\end{array}$ & $14 \%$ \\
\hline
\end{tabular}

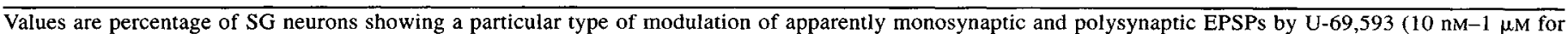

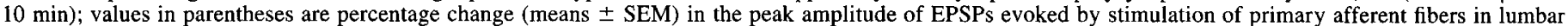

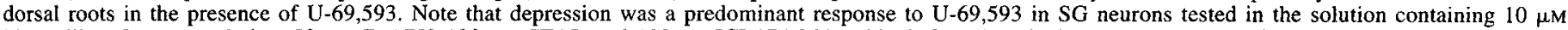

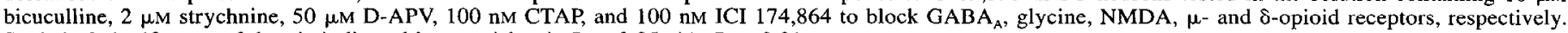
Statistical significance of data is indicated by asterisks: *, $P<0.05$; **, $P<0.01$.

the maximum (usually within $15 \mathrm{~min}$ after the drug removal from the perfusing medium), and the effects were long-lasting showing little recovery up to $30 \mathrm{~min}$ of recording (Fig. 7).

Pretreatment of slices with nor-BNI (100 nM) antagonized the depressant effect of dynorphin (10-100 nM) on monosynaptic EPSPs in 4 of $5 \mathrm{SG}$ cells examined (Fig. 8A,B). Antagonism of the potentiation of EPSP by dynorphin $(1 \mu \mathrm{M})$ was seen in one cell at a relatively high concentration $(10 \mu \mathrm{M})$ nor-BNI (Fig. $8 C, D$ ), leaving some doubt as to the $\kappa$-opioid specificity of its action. Although, as noted above, the bath application of norBNI at concentration of $100 \mathrm{nM}$ had no consistent effect on postsynaptic membrane potential or input resistance of SG neurons, it did produce a small decrease (to $87.6 \pm 2.1 \%$ ) in the peak amplitude of monosynaptic EPSPs in 11 of 13 SG neurons. Because of the depressant effect of nor-BNI, all of the antagonist experiments discussed above compared the amplitude of EPSPS measured in the presence of nor-BNI to the EPSPs recorded in the presence of both nor-BNI and dynorphin.

Effects of bicuculline, strychnine and D-2-amino-5phosphonovaleric acid on modulation of EPSPs by dynorphin

To exclude the possibility that a disinhibitory mechanism (Zieglgänsberger et al., 1979; Neumaier et al., 1988; Magnuson and Dickenson, 1991) might be involved in the dual modulation of EPSPs we examined the actions of dynorphin on EPSPs in 19 SG cells in the presence of bicuculline $(10 \mu \mathrm{M})$ and strychnine $(2 \mu \mathrm{M})$, the drugs known to block GABAergic and glycinergic inhibitory transmission. Although the dynorphin-induced depression (monosynaptic EPSPs: to $71.7 \% \pm 12.2,3 / 6$ cells; polysynaptic EPSPs: to $69.0 \% \pm 4.6,8 / 13$ cells) and enhancement (monosynaptic EPSPs: to $157.0,1 / 6$ cells; polysynaptic EPSPs: $142.0 \% \pm 17.4,4 / 13$ cells) of EPSPs remained after pharmacological blockade of inhibitory synaptic transmission, the proportion of cells in which dynorphin produced the enhancement of monosynaptic EPSPs was markedly reduced (Table 1, Fig. 9). The reduction of the enhancement of EPSPs in SG neurons by dynorphin in the presence of bicuculline and strychnine suggests that the excitatory effect of dynorphin may have been produced through inhibition of GABAergic and/or glycinergic inhibitory interneurons.

Dynorphin- and U-69,593-induced modulation of EPSPs in the presence of CTAP and ICI 174,864

To exclude the possibility that dynorphin may activate $\mu$-and/ or $\delta$-opioid receptors to produce depression or enhancement of EPSPs, the synaptic responses to bath application of $10 \mathrm{nM} d y-$ norphin were examined in slices superfused with a solution con- taining CTAP (10-100 nM) and ICI 174,864 (10-100 nM), in addition to bicuculline $(10 \mu \mathrm{M})$, strychnine $(2 \mu \mathrm{M})$, and D-APV $(50 \mu \mathrm{M})$. Dynorphin produced a reversible reduction in the peak amplitude of A $\delta$ fiber-evoked monosynaptic (to $79.0 \% \pm 2.7$ of control; $n=12 / 19$ ) and polysynaptic (to $69.7 \% \pm 3.7, n=3 / 4$ ) EPSPs in 15 of 23 SG cells examined (Fig. 10A,B; Table 1). In the remaining eight cells tested, dynorphin caused a reversible enhancement of the monosynaptic (to $126.7 \% \pm 9.4, n=7 / 19$ ) and polysynaptic EPSPs (to $133 \%, n=1 / 4$ ) (Fig. 10C,D; Table 1). Nor-BNI (10 nM) reversibly blocked the inhibitory effect of dynorphin on EPSPS in all of 4 cells tested, the result indicating the effect was probably mediated by the $\kappa_{1}$-opioid receptor (Fig. $11 A$ ). The excitatory effect of dynorphin appeared to be less sensitive to nor-BNI (10 nM); the response showed delayed onset and was reduced in magnitude $(n=4$, Fig. $11 B)$. Nor-BNI, in the absence of dynorphin, produced a small increase in the EPSP in 8 SG neurons. The enhancing effect of nor-BNI implies either a tonic endogenous $\kappa_{1}$-opioid action or some potent nonopioid receptor-mediated actions in the slice, similar to those described for naloxone (Alzheimer and Ten Bruggencate, 1990).

Addition of $0.01-1 \mu \mathrm{M} U-69,593$ to the perfusate produced a dose-dependent reduction in monosynaptic EPSPs (10 nM: to $75.5 \% \pm 8.0$ of control, $n=6 / 6 ; 100 \mathrm{nM}$ : to $55.5 \%, n-2 / 2$; $1 \mu \mathrm{M}$ : to $39.0 \% \pm 11, n=2 / 3$ ) in 10 of $11 \mathrm{SG}$ cells tested under conditions of pharmacological blockade of GABAergic and glycinergic synaptic inhibition and NMDA, $\mu$ - and $\delta$-opioid receptors (Fig. 12, Table 2). The depressant effect of $10 \mathrm{~nm}$ U-69,593 on EPSPs was associated with hyperpolarization $(-4.3 \pm 1.8 \mathrm{mV})$ in 5 of 6 cells examined.

\section{Inhibition of the dynorphin depression of excitatory transmission by $R p$-cAMPS}

In this series of experiments we focused on the possible intracellular mechanism by which dynorphin could cause the depression of EPSPs in SG neurons. Specifically, we asked whether the depression of EPSPs, observed in a majority of SG neurons under conditions of pharmacological blockade of synaptic inhibition and NMDA-, $\mu$-, and $\delta$-opioid receptors, is a consequence of the involvement of adenylate cyclase/cAMP-dependent protein kinase (PKA) system. We used external perfusion with Rp-cAMPS, a membrane permeant potent competitive inhibitor of PKA, in the presence of pharmacological blockade of synaptic inhibition (bicuculline $10 \mu \mathrm{M}$, glycine $2 \mu \mathrm{M}$ ) and NMDA (50 $\mu \mathrm{M}$ D-APV) $\mu$ - (100 nM CTAP), and $\delta-(100 \mathrm{nM}$ ICI 174,864 or $100 \mathrm{nM}$ naltrindol) opioid receptors, to determine whether the dynorphin depression could be reduced by this agent. The bath application of Rp-cAMPS (100 $\mu \mathrm{M}$ for $30 \mathrm{~min}$ ) 

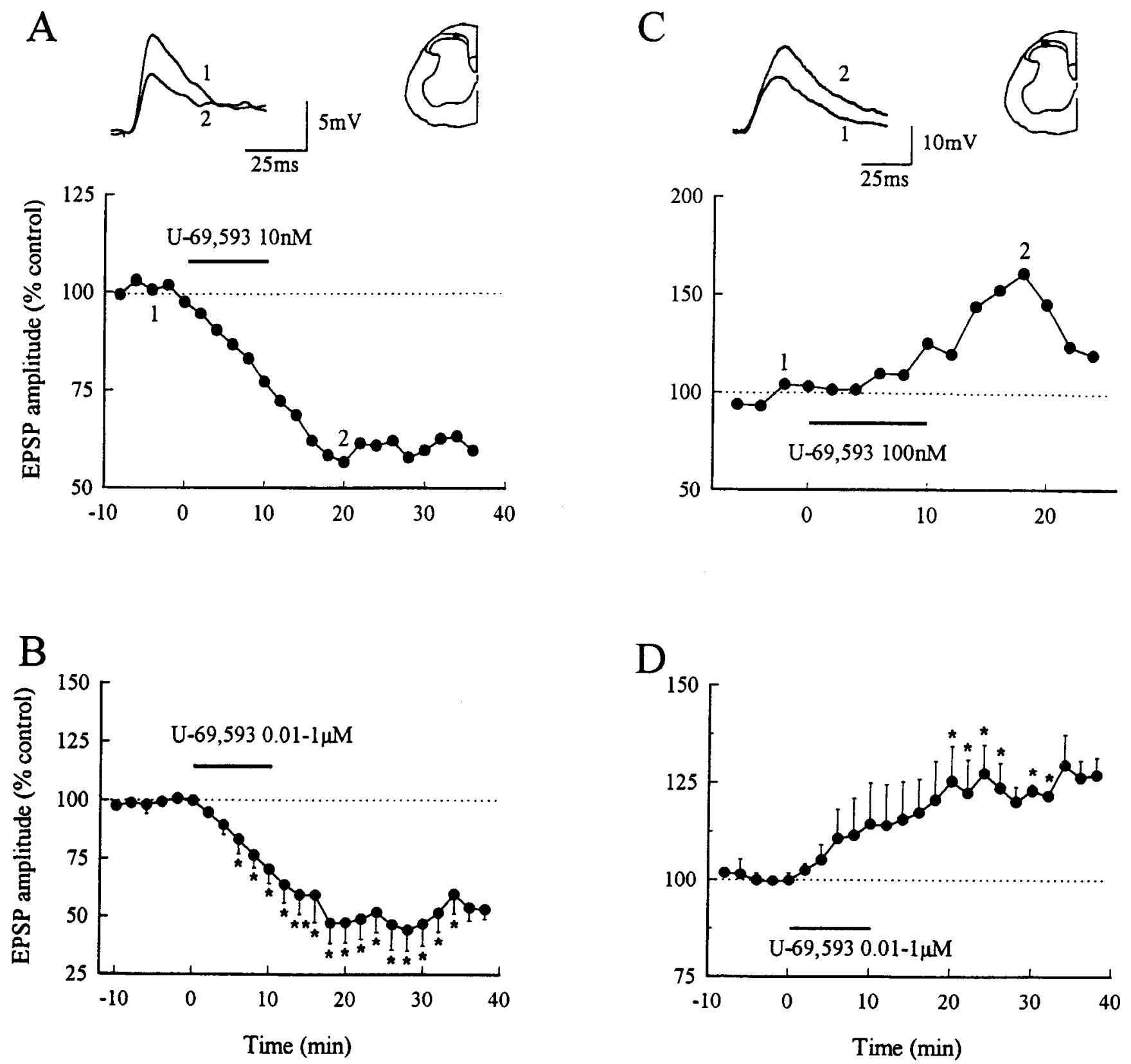

Figure 7. Dual modulation of A $\delta$-primary afferent fiber-evoked EPSPs by U-69,593. A, The graph shows the time course of changes in the peak amplitude of EPSPs, recorded intracellularly from a SG neuron (inset) in response to electrical stimulation $(5.5 \mathrm{~V}, 0.1 \mathrm{msec})$ of L5 dorsal root, produced by $10 \mathrm{nM}$ U-69,593. Note the long-lasting depression of EPSPs and a very little recovery. Above the graph are superimposed individual, apparently monosynaptic EPSPs taken before (trace 1) and 10 min (trace 2) after the removal of U-69,593. B, Pooled data obtained from 5 SG neurons show the time course of the depressant effect of U-69,593 $(0.01-1 \mu \mathrm{M})$ on the peak amplitude of EPSPs. $C$, In another SG neuron (inset), $100 \mathrm{nM} U-69,593$ produced potentiation of the peak amplitude of EPSPs (trace 2). $D$, Summarized data for 6 neurons showing the time course of long-lasting potentiation of the EPSPs produced by U-69,593 $(0.01-1 \mu \mathrm{M})$. Data are presented as mean \pm SEM of control value, the latter taken as average value of three consecutive responses prior to U-69,593 administration. Statistical difference: $*, P<0.05 ; * *, P<0.01$ from control is marked by asterisks. $A, V_{m}=-72 \mathrm{mV}, 24 \mathrm{~d}$ old rat. $B, V_{m}=-69$ to $-80 \mathrm{mV}, 17-24 \mathrm{~d}$ old rats. $C, V_{m}=-60 \mathrm{mV}, 20 \mathrm{~d}$ old rat. $D, V_{m}=-60$ to $-75 \mathrm{mV}, 18-22 \mathrm{~d}$ old rats.

had no consistent effect on postsynaptic membrane potential $(-1.7 \pm 0.9 \mathrm{mV}, n=11)$ or input resistance $(92 \% \pm 4.3$ of control, $n=7)$ or EPSPs $(99.7 \% \pm 11.5, n=12)$ of SG cells. However, Rp-cAMPS was an effective inhibitor of the depressant effect of $10 \mathrm{nM}$ dynorphin in 11 of $13 \mathrm{SG}$ cells examined (Fig. 13), whereas in the same cells, dynorphin (10 nM) alone caused a depression (to $76.0 \pm 5.8 \%, n=11 / 12$ ) of the peak amplitude of EPSPs.

\section{Discussion}

The role of dynorphin $A_{1-17}$ in regulation of EPSPs at primary afferent synapses with SG neurons was examined and the results indicate that the function of endogenous dynorphin $A_{1-17}$ in the excitatory glutamatergic synaptic transmission is complex. Dynorphin causes a dual modulation of primary afferent stimulation-evoked monosynaptic and polysynaptic EPSPs: it increased or decreased synaptic responses at nanomolar concentrations and 


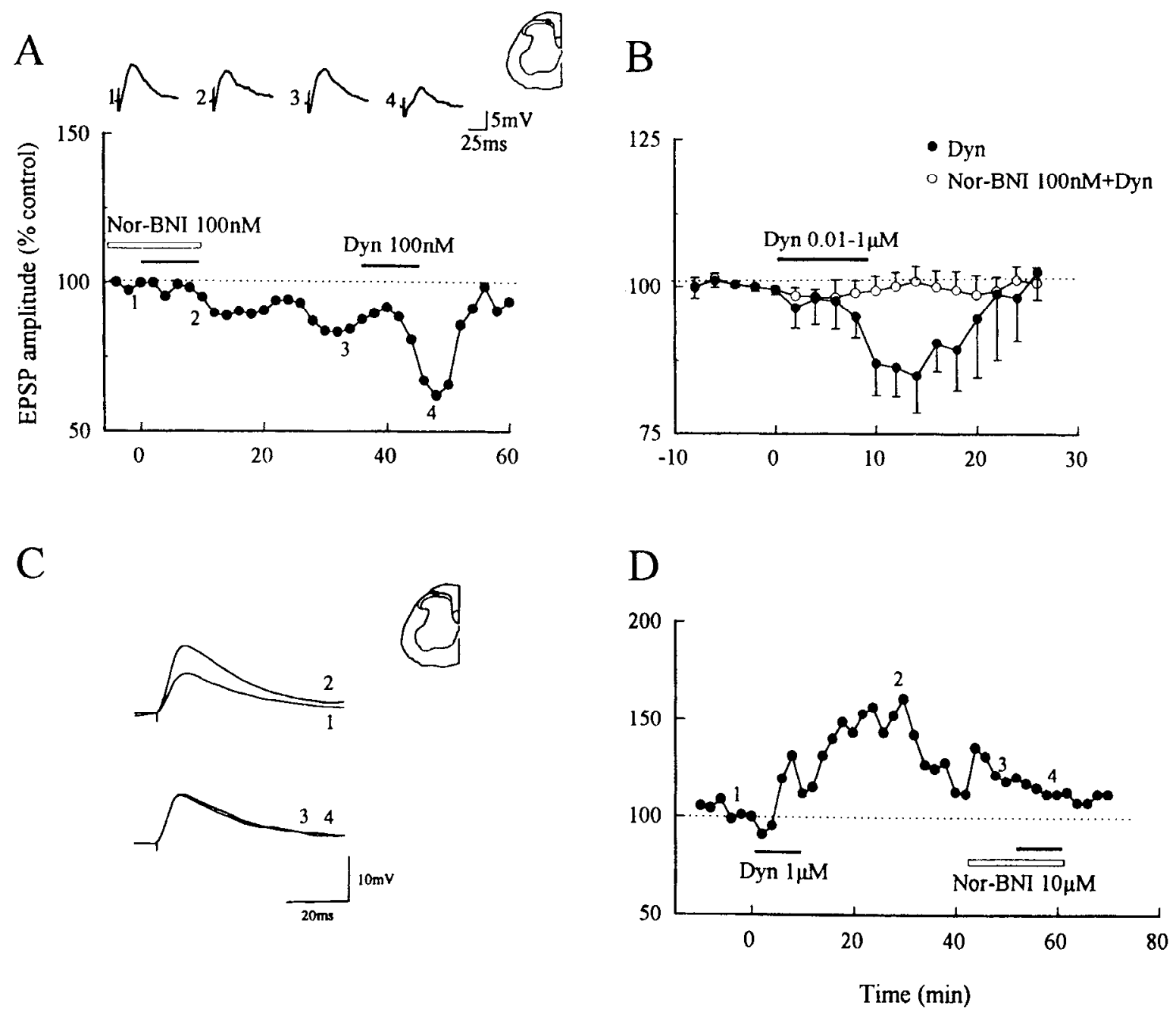

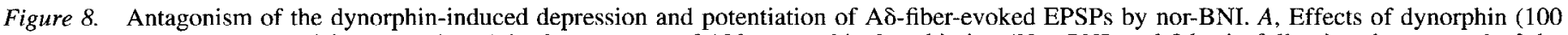
nM) recorded from the same SG neuron (inset) in the presence of $100 \mathrm{nM}$ norbinaltorphimine (Nor-BNI) and 26 min following the removal of the drug. Nor-BNI produced no change of EPSPs by itself (trace 1), but substantially reduced (trace 2) the depression of EPSPs induced by dynorphin alone (trace 4). The graph shows the time course of changes in the peak amplitude of EPSPs; above the graph are displayed individual EPSPs taken at times indicated on the graph. $B$, Summarized data showing the time course of the depression of EPSPs in 5 SG neurons produced by dynorphin alone (0.01-1 $\mu \mathrm{M}$, solid symbols) and antagonism of the depressant effect by nor-BNI (100 nM, open symbols). $C$ and $D$, In a different SG neuron (inset), superfusion of $1 \mu \mathrm{M}$ dynorphin potentiated the EPSPs during the peptide administration and 30 min after its removal. The enhancing effect of dynorphin was absent in the presence of $10 \mu \mathrm{M}$ nor-BNI. EPSPs recorded before (trace 1), after the removal of $1 \mu \mathrm{M}$ dynorphin (trace 2), in $10 \mu \mathrm{M}$ nor-BNI (trace 3) and dynorphin $(1 \mu \mathrm{M})+$ nor-BNI $(10 \mu \mathrm{M})$ (trace 4) are shown in $C . A, V_{m}=-78 \mathrm{mV}, 20 \mathrm{~d}$ old rat. $B, V_{m}$ $=-69$ to $-82 \mathrm{mV}, 19-23 \mathrm{~d}$ old rats. $C$ and $D, V_{m}=-73 \mathrm{mV}, 26 \mathrm{~d}$ old rat.

almost exclusively increased EPSPs at micromolar concentrations. As discussed below the results provide the first evidence that excitatory AMPA receptor-mediated primary afferent neurotransmission in the SG is inhibited by $\kappa_{1}$-opioid receptors. Although, the possibility that the excitatory effect of dynorphin on primary afferent neurotransmission results from inhibiton of GABA-ergic and glycinergic interneurons is supported by our data, the specificity of the dynorphin-induced potentiation for the $\kappa_{1}$-opioid receptors has been brought into question because of our inability to consistently and completely block this effect by a selective antagonist.

\section{Activation of $\kappa_{1}$-opioid receptors inhibits synaptic transmission}

Our major finding was that the activation of a receptor that shows similar pharmacology to that reported for the $\kappa_{1}$-opioid receptor (Nock et al., 1988, 1990; Zukin et al., 1988) reduces the peak amplitude of evoked EPSPs in a majority of SG cells.
Several lines of evidence support this conclusion. First, the peak amplitude of presumed monosynaptic and polysynaptic EPSPs was reduced in the presence of U-69,593, the $\kappa_{1}$-opioid receptor preferring ligand (Lahti et al., 1985), or dynorphin $A_{1 \text { - }}$ ${ }_{17}$, an endogenous opioid peptide that exhibits higher affinity for $\kappa_{1}$ - than $\kappa_{2}$-opioid binding sites in brain (Meng et al., 1993). Sccond, the depressant effect of dynorphin on EPSPs was blocked by the selective $\kappa_{1}$-opioid receptor antagonist, norbinaltorphimine (Portoghese et al., 1987; Takemori et al., 1988). Third, the depressant effect of dynorphin remained after pharmacological blockade of NMDA receptors, $\mathrm{GABA}_{\mathrm{A}}$ - and glycine-mediated synaptic inhibition, and in the presence of CTAP and ICI 174,864 , the agents known to selectively block $\mu$ - and $\delta$-opivid receptors (Cotton et al., 1984; Pelton et al., 1985; Kazmierski et al., 1988). This pattern of agonist and antagonist selectivity is consistent with binding selectivities of these agents for the $\kappa_{1}$-binding site (Nock et al., 1988, 1990; Zukin 

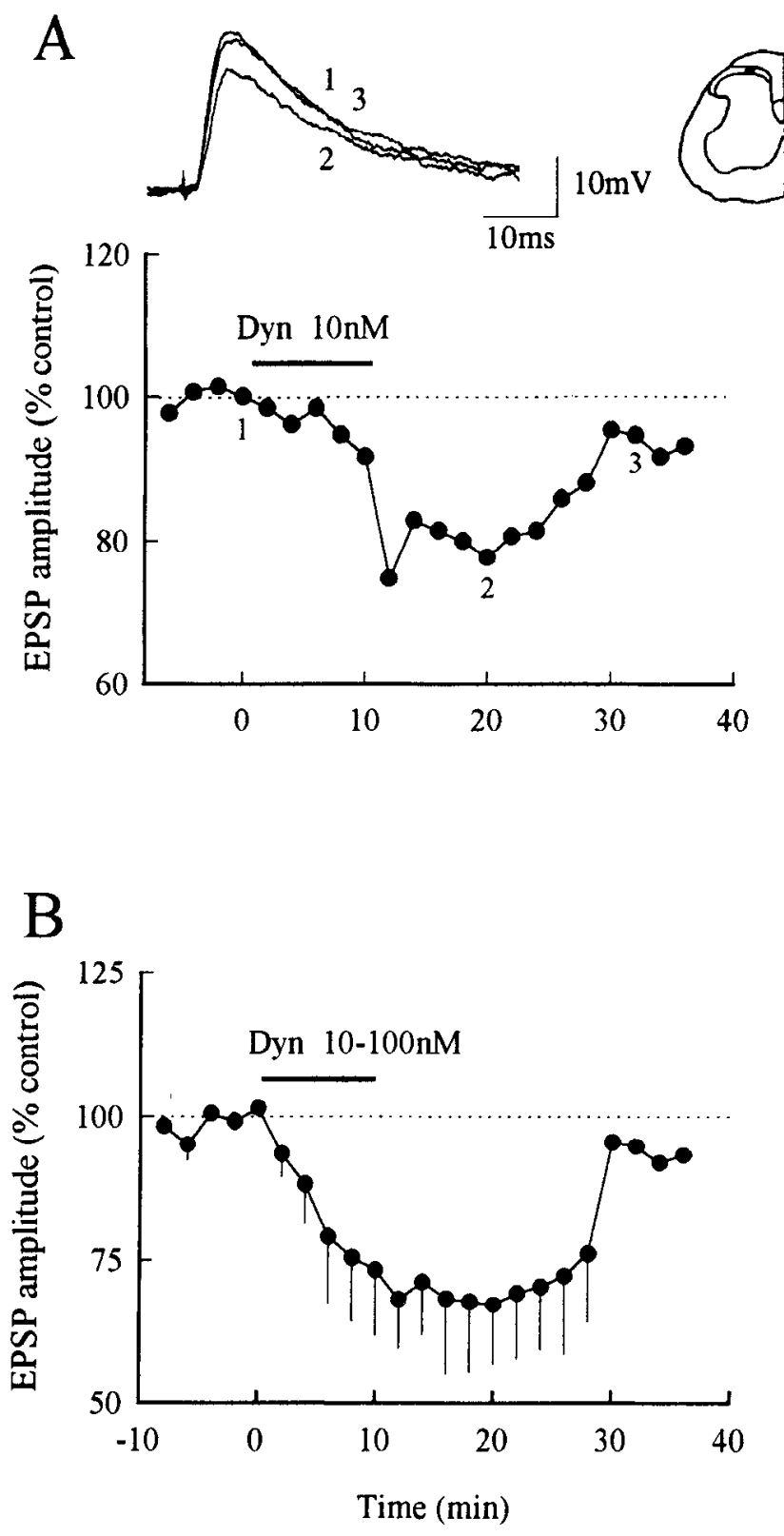

Figure 9. Depression of EPSPs by dynorphin $\mathrm{A}_{1-17}$ remains when GABA-ergic and glycinergic inhibitory transmission was blocked. $A$, The graph shows the time course of reduction of the peak amplitude of EPSPS recorded from a SG neuron (inset) in the presence of $10 \mu \mathrm{M}$

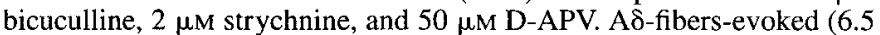
$\mathrm{m} / \mathrm{sec}$ ) presumably monosynaptic EPSPs recorded before (trace 1), 10 min (trace 2) and 22 min (trace 3) after the removal of dynorphin are superimposed above the graph. $B$. Summarized data showing the time course of the depression of apparently monosynaptic EPSPs for this and other two SG neurons produced by dynorphin (10-100 nM). $A, V_{m}=$ $-81 \mathrm{mV}, 23 \mathrm{~d}$ old rat. $B, V_{m}=-71$ to $-81 \mathrm{mV}, 19-23 \mathrm{~d}$ old rats.

et al., 1988; Meng et al., 1993). Our conclusion that the inhibitory effect of dynorphin $A_{1-17}$ and $U-69,593$ on the excitatory synaptic transmission is likely to be mediated by $\kappa_{1}$-receptors, is consistent with the reports (Allerton et al., 1989; James et al., 1990) that $\kappa_{1}$-receptors predominate in spinal cord of young rats and that dynorphin $A_{1-17}$ is present in the superficial spinal dorsal horn (DH) (Duggan and Fleetwood-Walker, 1993). The ability of $U 69,593$ to activate the $\kappa_{1}$-opioid receptor and elicit physiological effects indicates that this subtype of $\kappa$-receptor is a functionally coupled opioid receptor in the SG of spinal cord. Studies of the guinea pig dentate gyrus (Wagner et al., 1992, 1993), mossy fiber-CA3 pathway in the hippocampus (Weisskopf et al., 1993), locus coeruleus (McFadzean et al., 1987; Pinnock et al., 1992a), rat dorsal raphe nucleus (Pinnock et al., 1992b) and deep DH (Allerton et al., 1989) support a role for the $\kappa_{1}$-receptor in reducing glutamate-mediated excitatory synaptic transmission in the brain. The enhancing effect of nor-BNI, in the absence of $\kappa$-agonist and after pharmacological blockade of synaptic inhibition and NMDA-, $\mu-$, and $\delta$-opioid receptors, supports the contention that dynorphin, or a dynorphin-like peptide, is an endogenous agonist for the $\kappa_{1}$ receptors and that a physiological role of the endogenous dynorphin present in primary afferents and $\mathrm{DH}$ neurons may be to activate $\kappa_{1}$-receptors in the $S G$ to regulate excitability of this region.

\section{Possible sites of action and cellular mechanism of the dynorphin depression of EPSPS}

At present we do not know the mechanism of the $\kappa_{1}$-opioid receptor-mediated modulation of synaptic responses in the SG region. In principle, dynorphin could regulate excitatory synaptic transmission by modulating the presynaptic release of glutamate or the postsynaptic actions of glutamate. Dynorphin, and nonpeptide $\mathrm{k}$-agonists, could affect the excitability of a DH neuron postsynaptically by several mechanisms: (1) hyperpolarizing the neuronal membrane by directly opening and/or closing ion channels or acting through intracellular second messengers, (2) modulating the actions of glutamate, or (3) acting as glutamate receptor antagonists. The latter possibility, however, is not consistent with the ability of nor-BNI to block the actions of dynorphin $A_{1-17}$ and U-69-593.

The hyperpolarization through increases in membrane conductance is one way in which the $\kappa$ opioid agonists could inhibit the transfer of noxious input to other central sites in the nociceptive pathway. In contrast to the well known direct hyperpolarizing action of $\mu$-receptor agonists (Murase et al., 1982; Yoshimura and North, 1983; North, 1993; Grudt and Williams, 1994), the actions of $\kappa$-opioid receptor agonists at the level of single cell in the spinal cord remained unknown until recently. Using an in vitro slice preparation from guinea pig spinal trigeminal nucleus, Grudt and Williams (1993) showed that about $35 \%$ of $\mathrm{SG}$ neurons are hyperpolarized by $\mathrm{U}-69,593$ via an increase in potassium conductance, and that nor-BNI selectively blocked the hyperpolarization. Although dynorphin also caused hyperpolarization, the effect was reduced by naloxone and higher concentration of nor-BNI. These authors suggested that dynorphin was predominantly acting at $\mu$-opioid receptors, but it was still not possible to rule out an additional action at $\kappa_{2}$-receptors. Under the conditions of blockade of synaptic transmission with TTX and $\mu$ - and $\delta$-opioid receptors, dynorphin $\mathrm{A}_{1-17}$ and $\mathrm{U}-69,593$, in the present study, hyperpolarized most of rat $S G$ neurons and decreased their input resistance, the findings suggesting that direct interaction of $\mathrm{k}$-agonists with a postsynaptic receptor is likely. Since $U-69,593$ and nor-BNI are selective for the $\kappa_{1}$ over the $\kappa_{2}$ subtype of $\kappa$-opioid receptors (Nock et al., 1990), the hyperpolarization caused by dynorphin $A_{1-17}$ and $U-69,593$ is likely to be mediated by the $\kappa_{1}$-opioid receptors. Besides $\mathrm{K}^{+}$conductance (Grudt and Williams, 1993), k-opioids may modify other ionic conductances of SG neurons to interfere with synaptic response. The hyperpolarization of presynaptic nerve ter- 
A
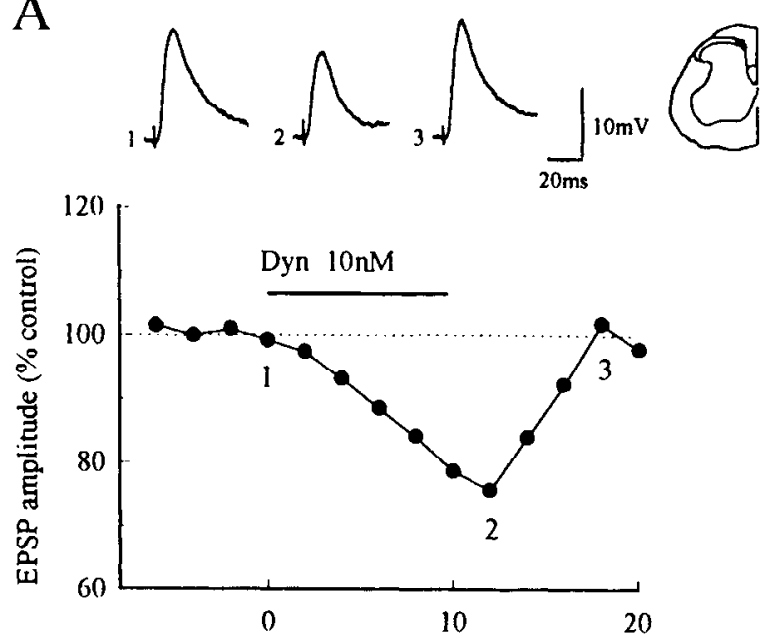

$\mathrm{B}$

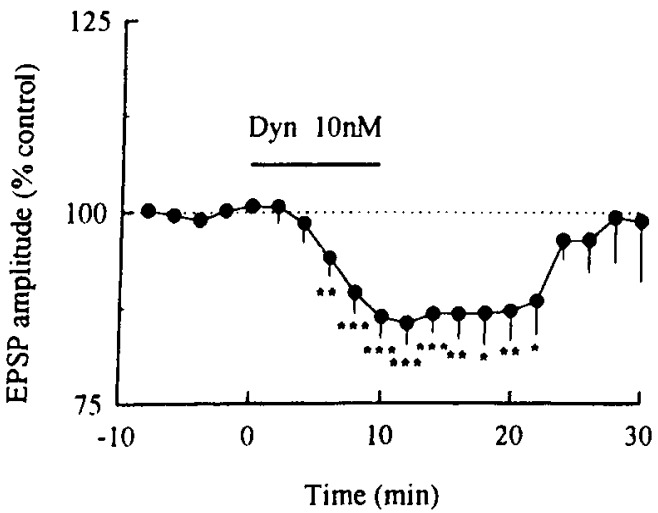

$\mathrm{C}$
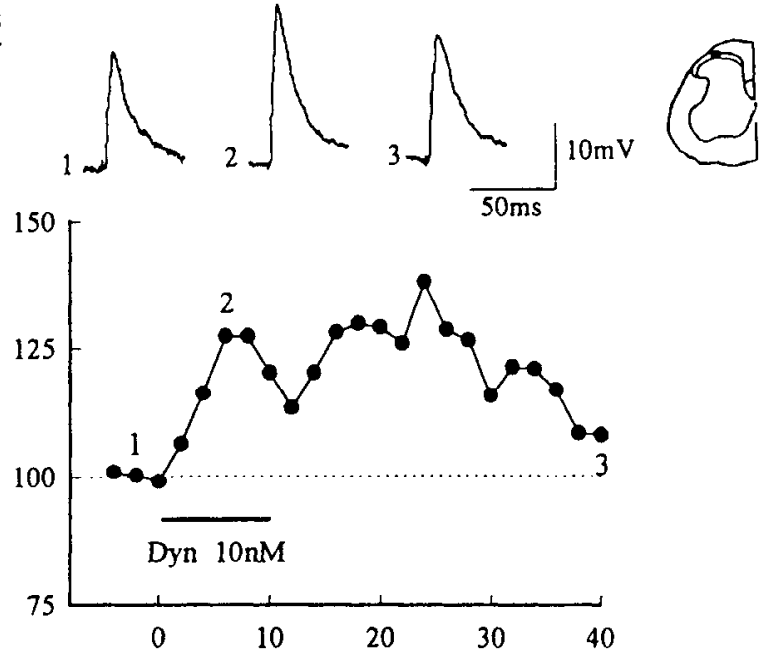

$\mathrm{D}$

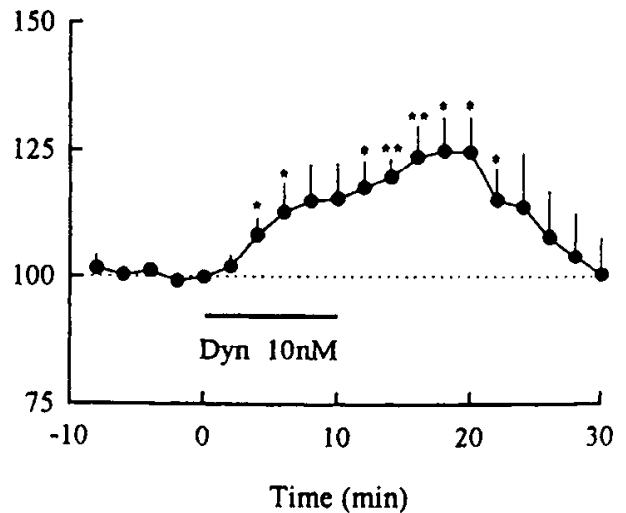

Figure 10. The dynorphin-induced depression and enhancement of EPSPs remains after pharmacological blockade of GABA ${ }_{A}^{-}$glycine-, NMDAand $\mu$-, and $\delta$-opioid receptors. $A$, The graph shows the time course of $10 \mathrm{nM}$ dynorphin-induced depression of EPSPS recorded from a SG neuron (inset) in the presence of $10 \mu \mathrm{M}$ bicuculline, $2 \mu \mathrm{M}$ strychnine, $50 \mu \mathrm{M}$ D-APV, $100 \mathrm{~nm}$ CTAP, and $100 \mathrm{nM}$ ICI 174,864. Above the graph are displayed individual apparently monosynaptic EPSPs recorded before (trace 1), 2 min (trace 2) and 8 min (trace 3) after the removal of dynorphin. $B$, Summarized data showing the time course of the depression of EPSPs for 12 SG neurons produced by 10 nM dynorphin. $C$, Plot of peak EPSP amplitude versus time shows the complete time course of the dynorphin-induced potentiation of synaptic response in a SG neuron (inset) perfused with the same medium, as shown in A. The numbers correspond to the respective individual apparently monosynaptic EPSPs shown above the graph. $D$, Summarized data for 7 SG neurons showing potentiation of EPSPs by $10 \mathrm{nM}$ dynorphin. Statistical significance of data is indicated by asterisks: *, $P<0.05$; **, $P<0.01$; ***, $P<0.001 . A, V_{m}=-76 \mathrm{mV}, 25 \mathrm{~d}$ old rat. $B, V_{m}=-66$ to $-76 \mathrm{mV}, 19-27 \mathrm{~d}$ old rats. $C, V_{m}=-77$ $\mathrm{mV}, 26 \mathrm{~d}$ old rat. $D, V_{m}=-64$ to $-77 \mathrm{mV}, 19-27 \mathrm{~d}$ old rats.

minals in the ciliary ganglion by $\kappa$-opioids appears to result from inhibition of the $\mathrm{Na}^{+}-\mathrm{K}^{+}$inward rectifier current (Fletcher and Chiapinelli, 1993). $\mathrm{Ca}^{2+}$ conductance in DH neurons (Bean, 1989) and $\left[\mathrm{Ca}^{2+}\right]_{i}$ (Cerne et al., 1985) might also be altered by $\kappa$-opioids. In most $\mathrm{CA} 3$ hippocampal neurons, the voltage-dependent $\mathrm{K}^{+}$current, known as the M-current, is uniquely sensitive to the $\kappa$-opioids with the direction of response dependent upon the $\kappa$-opiate receptor type and concentration (Moore et al., 1994).

A second observation suggesting that the inhibitory effect of the $\kappa$-opioids on EPSPs in SG neurons is likely mediated by a postsynaptic interaction of $\kappa$-agonists with the glutamate receptor is supported by our recent findings that $\kappa$-opioids at concentrations that reduce EPSPs also reduce sensitivity of AMPA/KA and NMDA subtypes of glutamate receptor in acutely isolated neurons from the rat DH (Kolaj et al., 1992, 1993, 1995; Cerne et al., 1993, 1995; Randić et al., 1995).

Reducing activation of SG neurons by primary afferent fibers provides another way in which $\kappa$-opioid agonists might interfere with the perception of pain stimuli. The inhibition was most likely of presynaptic origin in some SG cells, since dynorphin $A_{1-17}$ and U-69,593 did depress the EPSPs (in the presence of $\mu$ - and $\delta$ - blocking agents) in the absence of any changes in membrane potential and input resistance. This conclusion is in agreement with other studies (McFadzean et al., 1987; Allerton et al., 1989; Pinnock et al., 1992; Wagner et al., 1992; Weisskopf et al., 1993) suggesting a decrease in excitatory transmitter release at presynaptic terminals by $\kappa$-opioids. In agreement with this concept is the finding that the activation of $k$-receptors inhibited excitatory amino acids release in the hippocampus (Wag- 
A
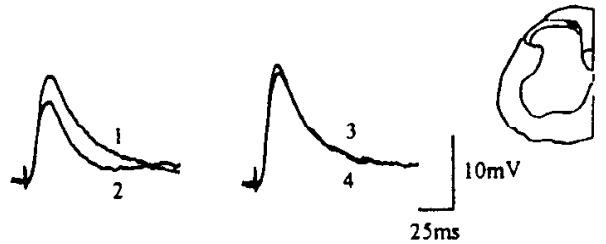

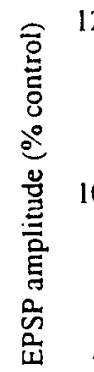

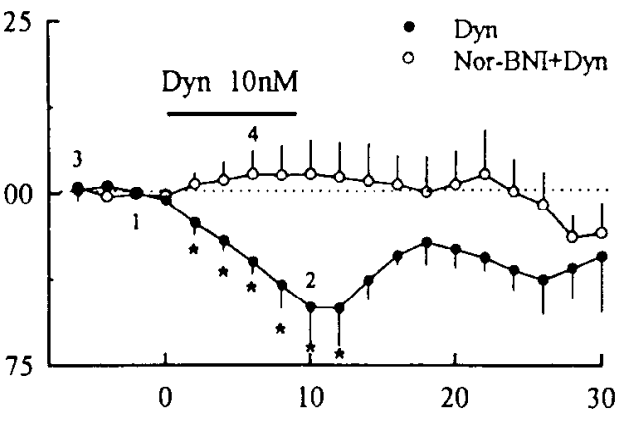

Time $(\min )$
$\mathrm{B}$
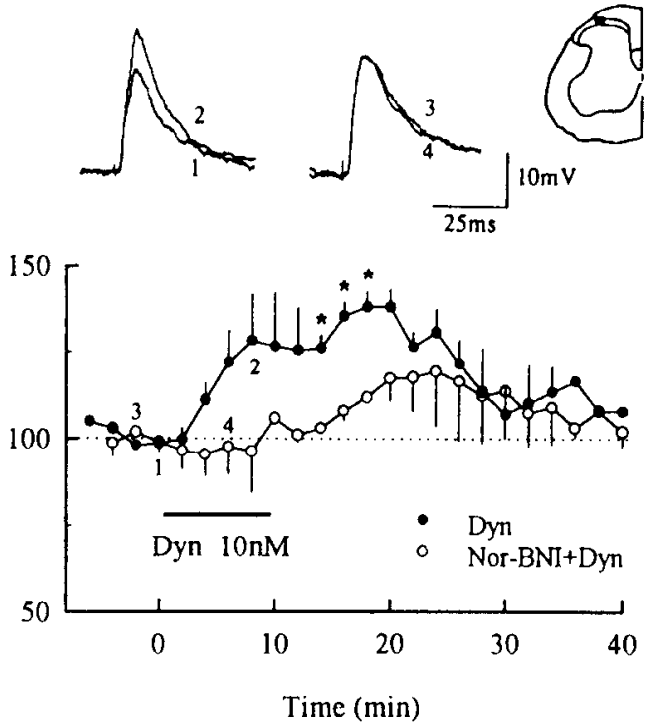

Figure 11. Antagonism of the dynorphin-induced depression and potentiation of EPSPs by nor-BNI after blockade of GABA $\mathrm{A}^{-}$, glycine-, NMDA-, and $\mu$ - and $\delta$-opioid receptors. A, Summarized data for 4 SG neurons showing the depression of EPSPs by 10 nM dynorphin in the presence of 10 $\mu \mathrm{M}$ bicuculline, $2 \mu \mathrm{M}$ strychnine, $50 \mu \mathrm{M}$ D-APV, $100 \mathrm{nM}$ CTAP, and $100 \mathrm{nM}$ ICI 174,864 (solid symbols) and antagonism of the depressant effect by nor-BNI (10 nM, open symbols). The numbers correspond to the respective individual apparently monosynaptic EPSPs recorded from a SG neuron (inset) and shown superimposed above the graph. $B$, Summarized data for 3 SG neurons showing the potentiation of EPSPs by 10 nM dynorphin in the medium as stated in $A$, and the effect of $10 \mathrm{~nm}$ nor-BNI. Statistical significance of data is indicated by an asterisk: $*$, $P<0.05$. $A, V_{m}=-71$ to $-76 \mathrm{mV}, 23-25 \mathrm{~d}$ old rats. $B, V_{m}=-66$ to $-77 \mathrm{mV}, 22-25 \mathrm{~d}$ old rats.

ner et al., 1992, 1993). Whether the inhibition of transmittcr release caused by $\kappa_{1}$-receptors results from a direct effect on calcium entry into the nerve terminal or indirectly by an increase in potassium conductance is not yet known, but previous studies have shown that $\mathrm{k}$-receptors can directly regulate calcium (Macdonald and Werz, 1986; Gross and Macdonald, 1987) and potassium conductances (Fletcher and Chiapinelli, 1993; Grudt and Williams, 1993). The cell bodies from which primary afferent fibers originate are in the dorsal root ganglion that is usually not included in the transverse spinal cord slice. The decrease of excitatory transmitter release (glutamate) from activated primary afferent fibers is therefore likely to be an action at or near the nerve terminals. The presence of $\kappa$-opioid receptors on primary afferent fibers and terminals is indicated by a loss of $\kappa$-receptors after dorsal rhizotomy (Besse et al., 1992).

The cellular targeting of the multiple opioid receptor proteins and their spatial relationship to cndogenous ligands has been extensively studied recently in the brain and spinal cord using antisera generated against $\mu-, \delta$-, and $\kappa$-opioid receptors. Thus, the results showed that the cloned $\delta$-opioid receptor is targeted into axons where it most likely functions presynaptically (Arvidsson et al., 1995a), whereas the cloned $\mu$-opioid receptor is preferentially targeted to the somatodendritic region and may function postsynaptically (Arvidsson et al., 1994). In a recent study, Arvidsson et al., (1995b) have raised antisera against a synthetic peptide corresponding to the carboxy terminus of the $\kappa$-opioid receptor. Results indicate that although in the rat and guinea pig brain, $\kappa$-opioid receptor in neurons is localized in both the axonal and somatodendritic compartments, immunostaining appears to be prevalent in the somatodendritic compartment. These findings suggest that the $\kappa$-opioid receptor is primarily, but not exclusively, localized in the postsynaptic membrane where it may mediate the effects of products of preprodynorphin and possibly preproenkephalin.
Besides depressing monosynaptic EPSPs, dynorphin $\mathrm{A}_{1-17}$ and U-69,593 also reduced the polysynaptic EPSPs in a majority of SG cells, but it is not possible to identify a site of action. $\kappa$ -Opioids may inhibit the interneurons directly by hyperpolarization or may act presynaptically to modify transmitter release, as shown for other types of opioid receptors (Arvidsson et al., 1995). The latter action could happen at synapses between primary afferents and interneurons or it could occur at synapses between interneurons.

At present we do not know the molecular mechanism(s) of the $\kappa_{1}$-opioid receptor inhibition of the excitatory glutamatergic transmission. There is no evidence that the $\kappa_{1}$-receptors are directly coupled to the AMPA/KA receptor complex. However, it is known that G-protein coupled adenylate cyclase/cAMP dependent protein kinase (PKA) system is one of the intracellular pathways negatively coupled to $\kappa$-opioid receptor activation (Childers, 1993). Previous and present results indicate that the $\kappa$-opioid receptor-mediated reduction of EPSPs in rat SG neurons may involve PKA for several reasons. The SG contains high density of binding sites for forskolin (Worley et al., 1986), and a membrane permeant analog of cAMP, 8-BrcAMP, or a phosphodiesterase inhibitor, IBMX, modulate the EPSPs and depolarizing responses to AMPA, KA and NMDA in DH neurons (Cerne et al., 1992). The long-lasting duration of the $\kappa$-opioid's effect on synaptic responses in SG neurons suggests that intracellular mechanism(s) is involved. In addition, we have shown in the present work that Rp-cAMPS, a membrane permeant potent, competitive inhibitor of PKA, was an effective inhibitor of the depressant effect of dynorphin $\mathrm{A}_{1-17}$ on the synaptic responses in SG cells. The latter result suggests that the reduction in the activity of PKA plays an important role in the mechanism by which dynorphin produces depression of primary afferentevoked EPSPs. Exactly how the synaptic function is altered by dynorphin and Rp-cAMPS is at present not clear. 

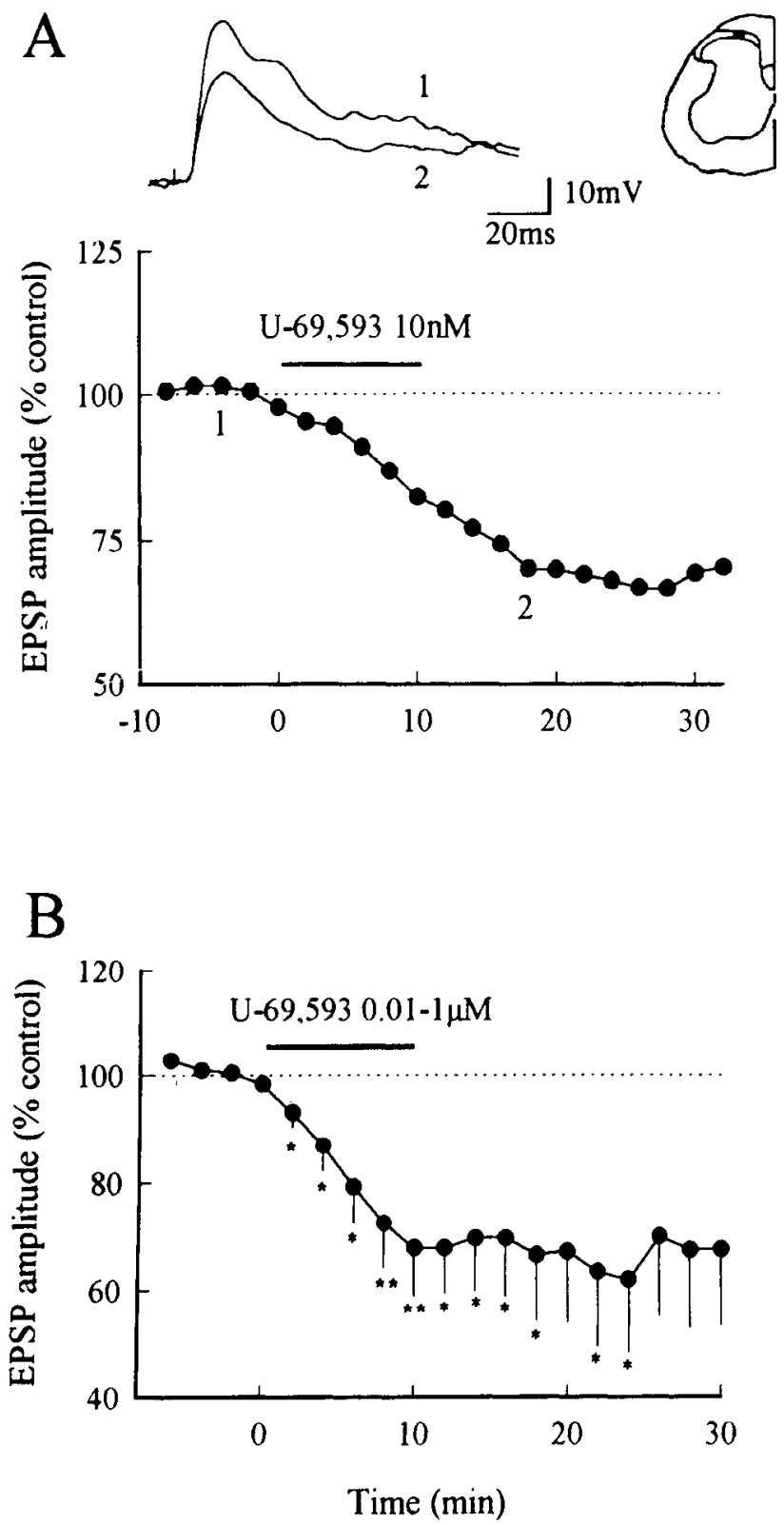

Figure 12. Depression of A8-fiber-evoked EPSPs by U-69,593 remains after blockade of $\mathrm{GABA}_{\mathrm{A}^{-}}$, glycine-, NMDA-, and $\mu$-, and $\delta$ opioid receptors. $A$, The graph shows the time course of reduction of the peak amplitude of EPSPs recorded from a SG neuron (inset) in the presence of $10 \mu \mathrm{M}$ bicuculline, $2 \mu \mathrm{M}$ strychnine, $50 \mu \mathrm{M}$ D-APV, 100 nM CTAP, and $100 \mathrm{nM}$ ICI 174,864. A $\delta$-fiber-evoked ( $4 \mathrm{~m} / \mathrm{sec})$ EPSPs recorded before (trace 1 ) and $8 \mathrm{~min}$ (trace 2) after the removal of 10 nM U69,593 are superimposed above the graph. $B$, Summarized data showing the time course of the depression of EPSPs for this and other 9 neurons produced by U-69,593 $(0.01-1 \mu \mathrm{M})$. Statistical significance of data is indicated by asterisks: *, $P<0.05$;*, $P<0.01 . A, V_{m}=$ $-75 \mathrm{mV}, 24 \mathrm{~d}$ old rat. $B, V_{m}=-62$ to $-87 \mathrm{mV}, 20-26 \mathrm{~d}$ old rats.

Excitatory effect of dynorphin $A_{1.17}$ and $U-69,593$ on primary afferent neurotransmission

As mentioned earlier, besides the depressant effect of dynorphin $A_{I-17}$, the majority of $S G$ neurons showed enhanced synaptic responses to primary afferent input in the presence of dynorphin $A_{1-17}$ and $U-69,593$ in slices perfused with a Krebs-bicarbonate solution (Fig. 3, Tables 1, 2). Increasing activation of SG neurons by primary afferent fibers provides one way in which $\kappa-$ opioid agonists might enhance EPSPs. In contrast to the result that $\kappa$-opioids decrease excitatory amino acid release in the hippocampus (Wagner et al., 1992) dynorphin $A_{1-17}$, dynorphin $A_{1-13}$, and $U-50,488 \mathrm{H}$ were reported to enhance glutamate/aspartate release in the spinal DH in vivo (Bakshi et al., 1990; Faden, 1990; Skilling et al., 1992). Thus in the absence of significant changes in resting membrane potential and neuronal input resistance, the increased synaptic efficacy, as manifested by the increase in the amplitude of the evoked EPSP in a subset of the SG neurons could be due, at least in part, to increased probability of release of transmitter(s) presynaptically.

Several heuristic models have been proposed to account for the variable effects of dynorphin in other brain regions and may also apply to the SG. One possible explanation for the bimodal pattern of the modulation of excitatory transmission by $\kappa$ opioids is that individual SG neurons have different opioid receptor subtypes that are selectively activated by different dynorphin concentrations or dynorphin fragments that produce qualitatively different responses. Indeed, it is known that dynorphin is a preferential $\kappa$ agonist at low concentrations (Chavkin et al., 1982), whereas at high concentrations it displays also affinity for $\mu$ - and $\delta$-receptors (Corbett et al., 1993). Moreover, there is evidence for multiple $\kappa$-binding sites $\left(\kappa_{1}, \kappa_{2}, \kappa_{3}\right)$ in the rat spinal DH (Zukin et all., 1988; Allerton et al., 1989; James et al., 1990; Nock et al., 1990). A range of endogenous opioids resulting from the processing of pre-prodynorphin precursors with differing profiles of receptor selectivity are found in the $\mathrm{DH}$, particularly in the marginal zone and substantia gelatinosa (Herman et al., 1980). It is further possible that the enzymatic cleavage patterns occurring in particular cells may differ so as to provide releasable opioids with different profiles of activity.

Although it is an attractive idea that the excitatory actions (depolarization and increase in EPSPS) of opioids on SG cells (Willcockson et al., 1986; Knox and Dickenson, 1987) might be due to activation of a particular $\kappa$-opioid receptor subtype, the possibility that the $\kappa$-opioids cause inhibition of a neighboring GABA-ergic and/or glycinergic inhibitory interneuron (Todd and Sullivan, 1990; Yoshimura and Nishi, 1995), or antagonism of endogenous GABA or glycine action resulting in a disinhibition, is supported by our data. Modulation of postsynaptic GA$\mathrm{BA}_{\mathrm{A}}$ receptors by dynorphin in freshly isolated spinal DH neurons has been recently observed (Wang and Randić, 1994). Excitations due to $\mu-, \delta$-, and $\kappa$-opioids have been reported in hippocampus (Zieglgänsberger, 1986) where a disinhibitory mechanism involving GABA-ergic interneuron has been postulated (Madison and Nicoll, 1988). Another possibility is that dynorphin, and other $\kappa$-opioids may act as $\mu$ opiate receptor antagonists (Dickenson and Knox, 1987; Corbett et al., 1993). This opens the possibility that dynorphin might reduce tonic opiate action and produce disinhibition in this manner. In addition, there is evidence that $\mathrm{\kappa}$-opioids may increase $\mathrm{K}^{+}$-evoked $\mathrm{SP}$ release from rat trigeminal nucleus caudalis slice (SuarezRoca and Maixner, 1993), which would be expected to produce depolarization and raise the excitability of neurons (Murase and Randić, 1984). Finally, к-opioids can display very pronounced excitatory nonopioid effects. The specificity of dynorphin and $k$ agonists for opioid receptors has been brought into question because of the often reported inability to block these effects by naloxone and nor-BNI (Walker et al., 1982; Knox and Dickenson, 1987; Caudle and Isaac, 1988; Faden, 1990; Chen et al., 1995). 
A

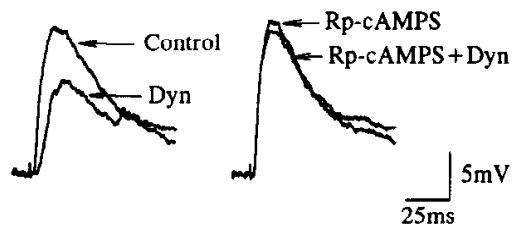

B

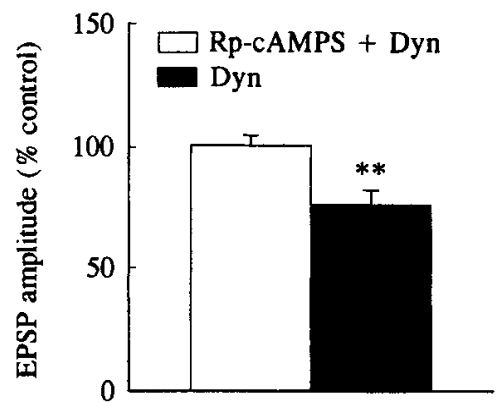

Figure 13. Blockade of the dynorphin $A_{1-17}$-induced depression of EPSPs by Rp-cAMPS. A, Superimposed traces are EPSPs recorded from a single SG neuron showing the depressant effect of $10 \mathrm{nM}$ dynorphin $\mathrm{A}_{1-17}$ (left traces) and its blockade by $100 \mu \mathrm{M}$ Rp-cAMPS (right traces) added to the perfusing medium containing $10 \mu \mathrm{M}$ bicuculline, $2 \mu \mathrm{M}$ strychnine, $50 \mu \mathrm{M}$ D-APV, $100 \mathrm{nM}$ CTAP, and $100 \mathrm{nM}$ ICI 174,84 or $100 \mathrm{nM}$ naltrindol. Rp-cAMPS was bath-applied $20 \mathrm{~min}$ prior to addition of dynorphin. $B$, Summarized results from the 13 SG neurons showing the depressant effect on EPSPs by $10 \mathrm{nM}$ dynorphin $\mathrm{A}_{1-17}$ in the absence (open bars, $n=11$ ) and presence (solid bars, $n=13$ ) of $100 \mu \mathrm{M}$ Rp-cAMPS. Data are presented as mcans \pm SEM. Statistical difference $(* *, P<0.01)$ between results obtained in the presence and absence of Rp-cAMPS is marked by an asterisk.

\section{Possible physiological and pathophysiological implications of inhibition of excitatory transmission by $\kappa$-opioids}

Evidence indicates that the AMPA receptor mechanism is essential for fast excitatory neurotransmission in the spinal cord (Forsythe and Westbrook, 1988; Gerber and Randić, 1989; Yoshimura and Jessell, 1989, 1990; Dougherty et al., 1992; King and Lopez-Garcia, 1993; Randić et al., 1993; Yoshimura and Nishi, 1993). In addition there is evidence which implicates dynorphin $\mathrm{A}_{1-17}$ and $\kappa$-opioid receptors in the physiology and pathophysiology of the spinal cord (Faden, 1990; Millan, 1990; Dubner and Ruda, 1992). Functional studies made in young and adult spinal cord support the involvement of $\kappa$-opioid receptors in the control of nociception (Duggan and Fleetwood-Walker, 1993). Dynorphin $\mathrm{A}_{1-17}$ and excitatory amino acids have both been implicated as pathophysiological factors in inflammation (Millan, 1990; Dubner and Ruda, 1992), stress (Millan, 1990), and trauma of spinal cord injury (Faden, 1990).

Although anatomical and neurochemical studies suggest that endogenous opioids act as neurotransmitters or neuromodulators, their roles in neuronal and pathophysiological regulation of synaptic transmission remained not defined until recently. Previous studies of the effects of opioid receptor agonists in slices of rat spinal cord concluded that excitatory afferent transmission was modulated predominantly by the $\mu$-opioid receptors (Jeftinija, 1988; Hori et al., 1992). However, Glaum et al. (1994) recently reported that the activation of either $\delta_{1}-$ or $\delta_{2}$-opioid receptors inhibits excitatory glutamatergic afferent transmission in the SG of the spinal cord of the rat. In the present work we have shown that the activation of $\kappa_{1}$-opioid receptors also inhibits primary afferent neurotransmission in the high proportion of SG neurons of young rats. Moreover, it has been recently shown that a receptor that bears similar pharmacology to that reported for the $\kappa_{2}$ /epsilon binding site (Nock et al., 1988, 1990; Zukin et al., 1988) inhibits NMDA-receptor-mediated synaptic responses in the hippocampus (Caudle et al., 1994). However, the pharmacological properties and anatomical distribution of the $\kappa_{2}$-receptors in the CNS and spinal cord remains controversial, due to the fact that there are no selective $\kappa_{2}$-receptor ligands. The inhibition of excitatory glutamatergic afferent transmission in the DH may underlie the ability of intrathecally administered $\mu-, \delta$-, and $\kappa$-opioid receptor agonists to produce antinociception (Yaksh, 1993).
The efficiency of synaptic transmission in the CNS, including spinal cord, is not constant and can be modulated by the rate of activity in presynaptic pathways. In a variety of brain structures (Madison et al., 1991) and the spinal cord (Randić et al., 1993), repetitive activation of synaptic connections can lead to longterm potentiation (LTP) or long-term depression (LTD) of excitatory synaptic transmission. There is cvidence implicating $\mu$-opioid peptides in the induction of LTP in the lateral perforant and mossy fiber pathways in the hippocampus (Bramham, 1992). In contrast, two recent reports suggest that dynorphin may reduce LTP in the hippocampus in a naloxone-reversible manner, at least in part by a presynaptic action (Wagner et al., 1993; Weisskopf et al., 1993). Whether dynorphin exerts a similar action on spinal neurons is not known. Since dynorphin is selectively released in the superficial DH by intense, high-frequency stimulation of unmyelinated primary afferent fibers or peripheral nerves (Yaksh et al., 1983; Hutchison et al., 1990), it is likely that this peptide may be involved in long-term regulation of activity-dependent changes in synaptic strength and neuronal excitability in the SG of the spinal cord.

In conclusion, we have shown that distinct dual modulation of synaptic efficiency can be induced at primary afferent synapses with neurons in young rat substantia gelatinosa by the activating $\mathrm{k}$-opioid receptors. Understanding the cellular mechanisms underlying the $\kappa_{1}$-agonist actions has implications both for the understanding of somatosensory processing in the spinal $\mathrm{DH}$, as well as for the development of novel analgesic strategies to prevent postinjury pain hypersensitivity.

\section{References}

Allerton CA, Smith JAM, Hunter JC, Hill RG, Hughes J (1989) Correlation of ontogeny with function of $\left[{ }^{3} \mathrm{H}\right] \mathrm{U} 69593$ labelled $\mathrm{K}$ opioid binding sites in the rat spinal cord. Brain Res 502:149-157.

Alzheimer C, Ten Bruggencate G (1990) Nonopioid actions of the $\kappa$-opioid receptor agonists, U50488H and U69593, on electrophysiological properties of hippocampal CA3 neurons in vitro. J Pharmacol Exp Ther 255:900-905.

Arvidsson U, Riedl M, Lee J-H, Nakano AH, Dado R, Chakrabarti S, Loh HH, Law P-Y, Yu L, Wessendorf MW, Elde R (1994) Cellular localization of a $\mu$-opioid receptor (MOR) in rat brain and spinal cord. Soc Neurosci Abstr 20:1483.

Arvidsson U, Dado RJ, Riedl M, Lee J-H, Law PY, Loh HH, Elde R, Wessendorf MW (1995a) $\delta$-Opioid receptor immunoreactivity: distribution in brain stem and spinal cord, and relationship to biogenic amines and enkephalin. J Neurosci 15:1215-1235. 
Arvidsson U, Riedl M, Chakrabarti S, Vulchanova L, Lee J-H, Nakano AH, Lin X, Loh HH, Law P-Y, Wessendorf MW, Elde R (1995b) The $\kappa$-opioid receptor is primarily postsynaptic: combined immunohistochemical localization of the receptor and endogenous opioids. Proc Natl Acad Sci USA 92:5062-5066.

Attali B, Gouardères C, Mazarguil H, Audigier Y, Cros J (1982) Evidence for multiple "kappa" binding sites by use of opioid peptides in the guinea-pig lumbo-sacral spinal cord. Neuropeptides 3:53-64.

Attali B, Saya D, Vogel Z (1989) к-Opiate agonists inhibit adenylate cyclase and produce heterologous desensitization in rat spinal cord. J Neurochem 52:360-369.

Atweh SF, Kuhar MJ (1977) Autoradiographic localization of opiate receptors in rat brain. I. Spinal cord and lower medulla. Brain Res 124:53-67.

Bakshi R, Newman AH, Faden AI (1990) Dynorphin $A_{1-17}$ induces alterations in free fatty acids, excitatory amino acids, and motor function through an opiate-receptor-mediated mechanism. J Neurosci 10: 3793-3800.

Bean BP (1989) Neurotransmitter inhibition of neuronal calcium currents by changes in channel voltage dependence. Nature 340:153156.

Besse D, Lombard MC, Zajac JM, Roques BP, Besson JM (1990) Preand postsynaptic distribution of $\mu, \delta$ and $\kappa$ opioid receptors in the superficial layers of the cervical dorsal horn of the rat spinal cord. Brain Res 521:15-22.

Bramham CR (1992) Opioid receptor dependent long-term potentiation: peptidergic regulation of synaptic plasticity in the hippocampus. Neurochem Int 20:441-455.

Brown AG (1982) The dorsal horn of the spinal cord. Q J Exp Physiol 67:193-212

Capogna M, Gähwiler BH, Thompson SM (1993) Mechanism of $\mu$ opioid receptor-mediated presynaptic inhibition in the rat hippocampus in vitro. J Physiol (Lond) 470:539-558.

Caudle RM, Isaac L (1988) Influence of dynorphin (1-13) on spinal reflexcs in the rat. J Pharmacol Exp Ther 246:508-513.

Caudle RM, Chavkin C, Dubner R (1994) $\kappa_{2}$ Opioid receptors inhibit NMDA receptor-mediated synaptic currents in guinea pig CA3 pyramidal cells. J Neurosci 14:5580-5589.

Cerne R, Jiang MC, Randić M (1992) Cyclic adenosine 3',5'-monophosphate potentiates excitatory amino acid and synaptic responses of rat spinal dorsal horn neurons. Brain Res 596:111-123.

Cerne R, Kolaj M, Jiang MC, Randić M (1993) Dynorphin-reduces synaptic and excitatory amino acid responses of rat spinal dorsal horn neurons. 32nd Int Congr Physiol Sci Abstract 299.7/0.

Cerne R, Kolaj M, Parpura V, Randić M (1995) Dynorphin modulates $N$-methyl-D-aspartate responses in acutely isolated neurons from the dorsal horn. J Neurosci, in press.

Cervero F, Iggo A (1980) The substantia gelatinosa of the spinal cord: a critical review. Brain 103:717-772.

Chavkin C, James IF, Goldstein A (1982) Dynorphin is a specific endogenous ligand of the kappa opioid receptor. Science 215:413-415.

Chen L, Gu Y, Huang L-YM (1995) The opioid peptide dynorphin directly blocks NMDA receptor channels in the rat. J Physiol (Lond) 482:575-581.

Childers SR (1993) Opioid receptor-coupled second messenger systems. In: Opioids I, Handbook of experimental pharmacology, Vol 104/ (Herz A, ed), pp 189-216. Berlin: Springer.

Clark JA, Liu L, Price M, Hersh B, Edelson M, Pasternak GW (1989) Kappa opiate receptor multiplicity: evidence for two U-50,488-sensitive $\kappa_{1}$ subtypes and a novel $\kappa_{3}$ subtype. J Pharmacol Exp Ther 251: $461-468$.

Coderre TJ, Katz J, Vaccarino AL, Melzack R (1993) Contribution of central neuroplasticity to pathological pain: review of clinical and experimental evidence. Pain 52:259-285.

Corbett AD, Paterson SJ, Kosterlitz HW (1993) Selectivity of ligands for opioid receptors. In: Opioids I, Handbook of experimental pharmacology, Vol 104/I (Herz A, ed), pp 645-679. Berlin: Springer.

Cotton R, Giles MG, Miller I, Shaw IS, Timms D (1984) ICI 174864 a highly selective antagonist for the opioid $\delta$-receptor. Eur J Pharmacol 97:331-332.

Cox BM (1993) Opioid receptor-G protein interactions: acute and chronic effects of opioids. In: Opioids I, Handbook of experimental pharmacology, Vol 104/I (Herz A, ed), pp 145-188. Berlin: Springer

Dougherty PM, Palecek J, Paleckova V, Sorkin LS, Willis WD (1992) The role of NMDA and non-NMDA excitatory amino acid receptors in the excitation of primate spinothalamic tract neurones by mechanical, chemical, thermal and electrical stimuli. J Neurosci 12:30253041

Dubner R, Ruda MA (1992) Activity-dependent neuronal plasticity following tissue injury and inflammation. Trends Neurosci 15:96-103.

Duggan AW, Fleetwood-Walker SM (1993) Opioids and sensory processing in the central nervous system. In: Opioids I, Handbook of experimental pharmacology, Vol 104/I (Herz A, ed), pp 731-771. Berlin: Springer.

Faden $\Lambda \mathrm{I}$ (1990) Opioid and nonopioid mechanisms may contribute to dynorphin's pathophysiologicl actions in spinal cord injury. Ann Neurol 27:67-74.

Fields HL, Emson PC, Leigh BK, Gilbert RFT, Iversen LL (1980) Multiple opiate receptor sites on primary afferent fibres. Nature 284:351353.

Fitzgerald M (1981) A study of the cutaneous afferent input to the substantia gelatinosa. Neuroscience 6:2229-2237.

Fleetwood-Walker SM, Hope PJ, Mitchell R, El-Yassir N, Molony V (1988) The influence of opioid receptor subtypes on the processing of nociceptive inputs in the spinal dorsal horn of the cat. Brain Res 451:213-226.

Fletcher GH, Chiappinelli VA (1993) The actions of the $\kappa_{1}$ opioid agonist $U-50,488$ on presynaptic nerve terminals of the chick ciliary ganglion. Neuroscience 53:239-250.

Forsythe ID, Westbrook GL (1988) Slow excitatory postsynaptic currents mediated by $N$-methyl-D-aspartate receptors on cultured mouse central neurones. J Physiol (Lond) 396:515-533.

Gerber G, Randić M (1989) Excitatory amino acid-mediated components of synaptically evoked input from dorsal roots to deep dorsa horn neurons in the rat spinal cord slice. Neurosci Lett 106:211-219.

Glaum SR, Miller RJ, Hammond DL (1994) Inhibitory actions of $\delta_{1}$-, $\delta_{2-}$ and $\mu$-opioid receptor agonists on excitatory transmission in lamina II neurons of adult rat spinal cord. J Neurosci 14:4965-4971.

Gouardères C, Audigier Y, Cros J (1982) Benzomorphan binding sites in rat lumbo-sacral spinal cord. Eur J Pharmacol 78:483-486.

Gross RA, Macdonald RL (1987) Dynorphin A selectively reduces a large transient ( $\mathrm{N}$-type) calcium current of mouse dorsal root ganglion neurons in cell culture. Proc Natl Acad Sci USA 84:5469-5473.

Grudt TJ, Williams JT (1993) к-Opioid receptors also increase potassium conductance. Proc Natl Acad Sci USA 90:11429-11432.

Grudt TJ, Williams JT (1994) $\mu$-Opioid agonists inhibit spinal trigeminal substantia gelatinosa neurons in guinea pig and rat. $\mathbf{J}$ Neurosci 14:1646-1654.

Herman BH, Leslie F, Goldstein A (1980) Behavioral effects and in vivo degradation of intraventricularly administered dynorphin-(1-13) and $D$ Ala ${ }^{2}$-dynorphin-(1-11) in rats. Life Sci 27:883-892.

Hope PJ, Fleetwood-Walker SM, Mitchell R (1990) Distinct antinociceptive actions mediated by different opioid receptors in the region of lamina I and laminae III-V of the dorsal horn of the rat. $\mathrm{Br} \mathrm{J}$ Pharmacol 101:477-483.

Hori Y, Endo K, Takahashi T (1992) Presynaptic inhibitory action of enkephalin on excitatory transmission in superficial dorsal horn of rat spinal cord. J Physiol (Lond) 450:673-685.

Hunter JC, Birchmore B, Woodruff R, Hughes J (1989) Kappa opioid binding sites in the dog cerebral cortex and spinal cord. Neuroscience 31:735-743.

Hutchison WD, Morton CR, Terenius L (1990) Dynorphin A: in vivo release in the spinal cord of the cat. Brain Res 532:299-306.

Hylden JLK, Nahin RL, Traub RJ, Dubner R (1991) Effects of spinal kappa-opioid receptor agonists on the responsiveness of nociceptive superficial dorsal horn neurons. Pain 44:187-193.

Ingram SL, Williams JT (1994) Opioid inhibition of $\mathrm{I}_{h}$ via adenylyl cyclase. Neuron 13:179-186.

Jahr CE, Jessell TM (1985) Synaptic transmission between dorsal root ganglion and dorsal horn neurons in culture: antagonism of monosynaptic excitatory postsynaptic potential and glutamate excitation by kynurenate. J Neurosci 5:2281-2289.

James IF, Fischli W, Goldstein A (1984) Opioid receptor selectivity of dynorphin gene products. J Pharmacol Exp Ther 228:88-93.

James IF, Bettaney J, Perkins MN, Ketchum SB, Dray A (1990) Opioid receptor ligands in the neonatal rat spinal cord: binding and in vitro depression of the nociceptive responses. Br J Pharmacol 99:503-508.

Jeftinija S (1988) Enkephalins modulate excitatory synaptic transmission in the superficial dorsal horn by acting at $\mu$-opioid receptor sites. Brain Res 460:260-268. 
Jin W, Lee NM, Loh HH, Thayer SA (1994) Opioids mobilize calcium from inositol 1,4,5-trisphosphate-sensitive stores in NG 108-15 cells. J Neurosci 14:1920-1929.

Kangrga I, Randić M (1991) Outflow of endogenous aspartate and glutamate from the rat spinal dors horn in vitro by activation of lowand high-threshold primary afferent fibers. Modulation by $\mu$-opioids. Brain Res 553:347-352.

Kazmierski W, Wire WS, Lui GK, Knapp RJ, Shook JE, Burks TF, Yamamura HI, Hruby VJ (1988) Design and synthesis of somatostatin analogucs with topographical properties that lead to highly potent and specific $\mu$ opioid receptor antagonists with greatly reduced binding at somatostatin receptors. J Med Chem 31:2170-2177.

King AE, Lopez-Garcia JA (1993) Excitatory amino acid receptormediated neurotransmission from cutaneous afferents in rat dorsal horn in vitro. J Physiol (Lond) 472:443-457.

Knox RJ, Dickenson AH (1987) Effects of selective and non-selective $\kappa$-opioid receptor agonists on cutaneous C-fiber-evoked responses of rat dorsal horn neurones. Brain Res 415:21-29.

Kojić Lj, Cheng G, Randić M (1994) Kappa opioid receptor activation modulates excitatory synaptic responses of the rat spinal dorsal horn neurons. Soc Neurosci Abstr 20:1738.

Kolaj M, Cerne R, Jiang MC, Lanthorn TH, Randić M (1992) The effects of dynorphin A (1-13) on glutamate and synaptic responses of rat spinal dorsal horn neurons. Soc Neurosci Abstr 18:281.

Kolaj M, Cerne R, Randić M (1993) Kappa opioid receptor activation modulates excitatory amino acid responses in acutely isolated neurons from the dorsal horn. Soc Neurosci Abstr 19:1382.

Kolaj M, Cerne R, Randic M (1995) The opioid peptide dynorphin modulates AMPA and kainate responses in acutely isolated neurons from the dorsal horn. Brain Res 671:227-244.

Kumazawa T, Perl ER (1978) Excitation of marginal and substantia gelatinosa neurons in the primate spinal cord: indications of their place in dorsal horn functional organization. J Comp Neurol 177: $417-434$.

Lahti RA, Mickelson MM, McCall JM, VonVoigtlander PF (1985) $\left[{ }^{3} \mathrm{H}\right] \mathrm{U}-69593$ a highly selective ligand for the opioid kappa-receptor. Eur J Pharmacol 109:281-284.

Lawrence DM, Bidlack JM (1993) The kappa opioid receptor expressed on the mouse R1.1 thymoma cell line is coupled to adenylyl cyclase through a pertussis toxin-sensitive guanine nucleotide-binding regulatory protein. J Pharmacol Exp Ther 266:1678-1683.

Light AR, Perl ER (1979) Spinal termination of functionally identified primary afferent neurons with slowly conducting myelinated fibers. J Comp Neurol 186:133-150.

Macdonald RL, Werz MA (1986) Dynorphin A decreases voltage-dependent calcium conductance of mouse dorsal root ganglion neurones. J Physiol (Lond) 377:237-249.

Madison DV, Nicoll RA (1988) Enkephalin hyperpolarizes interneurons in the rat hippocampus. J Physiol (Lond) 398:123-130.

Madison DV, Malenka RC, Nicoll RA (1991) Mechanisms underlying long-term potentiation of synaptic transmission. Annu Rev Neurosci 14:379-397.

Magnuson DSK, Dickenson AH (1991) Lamina-specific effects of morphine and naloxone in dorsal horn of rat spinal cord in vitro. $\mathrm{J}$ Neurophysiol 66:1941-1950.

McFadzean I, Lacey MG, Hill RG, Henderson G (1987) Kappa opioid receptor activation depresses excitatory synaptic input to rat locus coeruleus neurons in vitro. Neuroscience 20:231-239.

Meng F, Xie G-X, Thompson RC, Mansour A, Goldstein A, Watson SJ, Akil $H$ (1993) Cloning and pharmacological characterization of a rat $\kappa$ opioid receptor. Proc Natl Acad Sci USA 90:9954-9958.

Millan MJ (1990) Kappa-opioid receptors and analgesia. Trends Pharmacol Sci 11:70-76.

Miller KE, Seybold VS (1987) Comparison of met-enkephalin-, dynorphin $\mathrm{A}-$, and neurotensin-immunoreactive neurons in the cat and rat spinal cords. I. Lumbar cord. J Comp Neurol 255:293-304.

Miller KE, Seybold VS (1989) Comparison of met-enkephalin, dynorphin $\mathrm{A}$, and neurotensin immunoreactive neurons in the cat and rat spinal cords. II. Segmental differences in the marginal zone. J Comp Neurol 279:619-628.

Misawa II, Ueda II, Satoh M (1990) K-Opioid agonist inhibits phospholipase C, possibly via an inhibition of G-protein activity. Neurosci Lett 112:324-327.

Moises HC, Rusin KI, Macdonald RM (1994) $\mu$ - and $\kappa$-Opioid receptors selectively reduce the same transient components of high-thresh- old calcium current in rat dorsal root ganglion sensory neurons. J Neurosci 14:5903-5916.

Moore SD, Madamba SG, Schweitzer P, Siggins GR (1994) Voltagedependent effects of opioid peptides on hippocampal CA3 pyramidal neurons in vitro. J Neurosci 14:809-820.

Morris BJ, Herz A (1987) Distinct distribution of opioid receptor types in rat lumbar spinal cord. Naunyn-Schmiedebergs Arch Pharmacol 336:240-243.

Murase K, Randić M (1983) Electrophysiological properties of rat spinal dorsal horn neurones in vitro: calcium dependent action potentials. J Physiol (Lond) 334:141-153.

Murase K, Randić M (1984) Actions of substance P on rat spinal dorsal horn neurones. J Physiol (Lond) 346:203-217.

Murase K, Nedeljkov V, Randić M (1982) The actions of neuropeptides on dorsal horn neurons in the rat spinal cord slice preparation: an intracellular study. Brain Res 234:170-176.

Neumaier JF, Mailheau S, Chavkin C (1988) Opioid receptor-mediated responses in the dentate gyrus and CAl region of the rat hippocampus. J Pharmacol Exp Ther 244:564-570.

Nicoll RA, Alger BE, Jahr CE (1980) Enkephalin blocks inhibitory pathways in the vertebrate CNS. Nature 287:22-25.

Nock B, Rajpara A, O'Connor LH, Cicero TJ (1988) Autoradiography of $\left[{ }^{3} \mathrm{H}\right] \mathrm{U}-69593$ binding sites in rat brain: evidence for $\kappa$ opioid receptor subtypes. Eur J Pharmacol 154:27-34.

Nock B, Giordano AL, Cicero TJ, O'Connor LH (1990). Affinity of drugs and peptides for U-69,593-sensitive and -insensitive kappa opiate binding sites: the $U 69,593$-insensitive site appears to be the beta endorphin-specific epsilon receptor. J Pharmacol Exp Ther 254:412419.

North RA (1993) Opioid actions on membrane ion channels. In: Opioids I, Handbook of experimental pharmacology, Vol 104/I (Herz A, ed), pp 773-797. Berlin: Springer.

Nyberg F, Yaksh TL, Terenius L (1983) Opioid activity released from cat spinal cord by sciatic nerve stimulation. Life Sci 33(Suppl 1):1720.

Pelton JT, Gulya K, Hruby VJ, Duckles SP, Yamamura HI (1985) Conformationally restricted analogs of somatostatin with high $\mu$-opiate receptor specificity. Proc Natl Acad Sci USA 82:236-239.

Pinnock RD (1992a) A highly selective $\kappa$-opioid receptor agonist, CI977 , reduces excitatory synaptic potentials in the rat locus coeruleus in vitro. Neuroscience 47:87-94.

Pinnock RD (1992b) Activation of $\kappa$-opioid receptors depresses electrically evoked excitatory postsynaptic potentials on 5-HT-sensitive neurones in the rat dorsal raphé nucleus in vitro. Brain Res 583:237246.

Portoghese PS, Lipkowski AW, Takemori AE (1987) Binaltorphimine and nor-binaltorphimine, potent and selective $\kappa$-opioid receptor antagonists. Life Sci 40:1287-1292.

Randić M, Jiang MC, Cerne R (1993) Long-term potentiation and longterm depression of primary afferent neurotransmission in the rat spinal cord. J Neurosci 13:5228-5241.

Randić M, Kolaj M, Kojić Lj, Cerne R, Cheng G, Wang RA (1995) Interaction of neuropeptides and excitatory amino acids in the rat superficial spinal dorsal horn. Prog Brain Res, in press.

Rexed B (1952) The cytoarchitectonic organization of the spinal cord in the cat. J Comp Neurol 96:415-495.

Rhim H, Miller RJ (1993) Opioid modulation of evoked calcium signals in acutely dissociated neurons from the rat nucleus tractus solitarius (NTS). Soc Neurosci Abstr 19:420.

Rusin KI, Jiang MC, Cerne R, Randić M (1993) Interactions between excitatory amino acids and tachykinins in the rat spinal dorsal horn. Brain Res Bull 30:329-338.

Rustioni A, Weinberg RJ (1989) The somatosensory system. In: Handbook of chemical neuroanatomy, Vol 7, Integrated systems of the CNS, Pt II (Björklund A, Hökfelt T, Swanson LW, eds), pp 219-321. Amsterdam: Elsevier.

Schneider SP, Perl ER (1988) Comparison of primary afferent and glutamate excitation of neurons in the mammalian spinal dorsal horn. J Neurosci 8:2062-2073.

Simon EJ (1991) Opioid receptors and endogenous opioid peptides. Med Res Rev 11:357-374.

Skilling SR, Sun X-F, Kurtz HJ, Larson AA (1992) Selective potentiation of NMDA-induced activity and release of excitatory amino acids by dynorphin: possible roles in paralysis and neurotoxicity. Brain Res 575:272-278. 
Slater P, Patel S (1983) Autoradiographic localization of opiate $k$-receptors in the rat spinal cord. Eur J Pharmacol 92:159-160.

Stevens CW, Yaksh TL (1986) Dynorphin A and related peptides administered intrathecally in the rat: a search for putative kappa opiate receptor activity. J Pharmacol Exp Ther 238:833-838.

Stevens CW, Lacey CB, Miller KE, Elde RP, Seybold VS (1991) Biochemical characterization and regional quantification of $\mu, \delta$ and $\kappa$ opioid binding sites in rat spinal cord. Brain Res 550:77-85.

Suarez-Roca H, Maixner W (1993) Activation of kappa opioid receptors by $\mathrm{U}-50,488 \mathrm{H}$ and morphine enhances the release of substance P from rat trigeminal nucleus slices. J Pharmacol Exp Ther 264:648653.

Sugiura Y, Lee CL, Perl ER (1986) Central projections of identified, unmyelinated $(C)$ afferent fibers innervating mammalian skin. Science 234:358-361.

Sugiura Y, Terui N, Hosoya Y (1989) Difference in distribution of central terminals between visceral and somatic unmyelinated (C) primary afferent fibers. J Neurophysiol 62:834-840.

Takemori AE, Ho BY, Naeseth JS, Portoghese PS (1988) Nor-binaltorphimine, a highly selective kappa-opioid antagonist in analgesic and receptor binding assays. J Pharmacol Exp Ther 246:255-258.

Todd AJ, Sullivan AC (1990) Light microscope study of the coexistence of GABA-like and glycine-like immunoreactivities in the spinal cord of the rat. J Comp Neurol 296:496-505.

VonVoigtlander PF, Lahti RA, Ludens JH (1983) U-50,488: a selective and structurally novel non-mu (kappa) opioid agonist. J Pharmacol Exp Ther 224:7-12.

Wagner JJ, Caudle RM, Chavkin C (1992) Kappa-opioids decrease excitatory transmission in the dentate gyrus of the guinea pig hippocampus. J Neurosci 12:132-139.

Wagner JJ, Terman GW, Chavkin C (1993) Endogenous dynorphins inhibit excitatory neurotransmission and block LTP induction in the hippocampus. Nature 363:451-454.

Walker JM, Moises HC, Coy DH, Baldrighi G, Akil H. (1982) Nonopiate effects of dynorphin and des-Tyr-dynorphin. Science 218 : 1136-1138.

Wang RA, Randić M. (1994) Dynorphin $A_{1-17}$ reduces GABA $_{A}$ receptor-mediated responses in acutely isolated neurons from the spinal dorsal horn. Soc Neurosci Abstr 20:502.

Weisskopf MG, Zalutsky RA, Nicoll RA (1993) The opioid peptide dynorphin mediates heterosynaptic depression of hippocampal mossy fibre synapses and modulates long-term potentiation. Nature 362 : 423-427.

Willcockson WS, Kim J, Shin HK, Chung JM, Willis WD (1986) Actions of opioids on primate spinothalamic tract neurons. J Neurosci 6:2509-2520.

Worley PF, Baraban JM, De Souza EB, Snyder SH (1986) Mapping second messenger systems in the brain: differential localizations of adenylate cyclase and protein kinase C. Proc Natl Acad Sci USA 83: $4053-4057$.

Yaksh TL (1993) The spinal actions of opioids. In: Opioids II, Handbook of experimental pharmacology, Vol 104/I (Herz A, ed), pp 5390. Berlin: Springer

Yaksh TL, Terenius L, Nyberg F, Jhamandas K, Wang J-Y (1983) Studies on the release by somatic stimulation from rat and cat spinal cord of active materials which displace dyhydromorphine in an opiatebinding assay. Brain Res 268:119-128.

Yoshimura M, Jessell TM (1989) Primary afferent-evoked synaptic responses and slow potential generation in rat substantia gelatinosa neurons in vitro. J Neurophysiol 62:96-108.

Yoshimura M, Jessell TM (1990) Amino acid-mediated EPSPs at primary afferent synapses with substantia gelatinosa neurons in the rat spinal cord. J Physiol (Lond) 430:315-335.

Yoshimura M, Nishi S (1993) Blind patch-clamp recordings from substantia gelatinosa neurons in adult rat spinal cord slices: pharmacological properties of synaptic currents. Neuroscience 53:519-526.

Yoshimura M, Nishi S (1995) Primary afferent-evoked glycine and GABA-mediated IPSPs in substantia gelatinosa neurones in the rat spinal cord in vitro. J Physiol (Lond) 482:29-38.

Yoshimura M, North RA (1983) Substantia gelatinosa neurons hyperpolarized in vitro by enkephalin. Nature 305:529-530.

Yuan XR, Madamba S, Siggins GR (1992) Opioid peptides reduce synaptic transmission in the nucleus accumbens. Neurosci Lett 134: 223-228.

Zieglgänsberger W (1986) Central control of nociception. In: Handbook of physiology - the nervous system, Vol IV (Mountcastle VB, Bloom FE, Geiger SR, eds), pp 581-645. Baltimore: Williams and Wilkins.

Zieglgänsberger W, French ED, Siggins GR, Bloom FE (1979) Opioid peptides may excite hippocampal pyramidal neurons by inhibiting adjacent inhibitory interneurons. Science 205:415-417.

Zukin RS, Eghbali M, Olive D, Unterwald EM, Tempel A (1988) Characterization and visualization of rat and guinea pig brain $k$ opioid receptors: evidence for $\kappa_{1}$ and $\kappa_{2}$ opioid receptors. Proc Natl Acad Sci USA 85:4061-4065. 